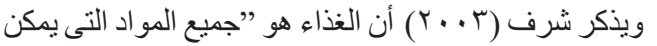

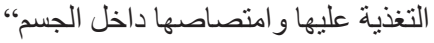

ويشير صالح (r . . r) أن الغذاء هو "مجموع الأطعمة التى

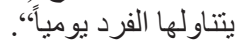

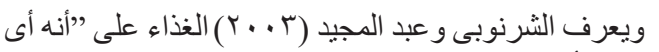

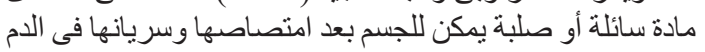

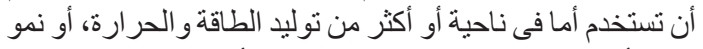

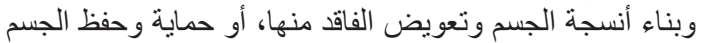

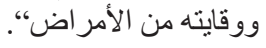

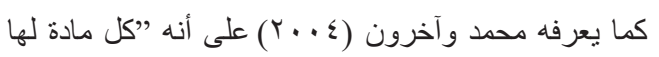

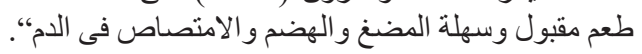

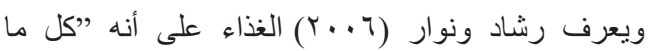

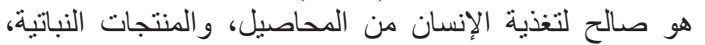

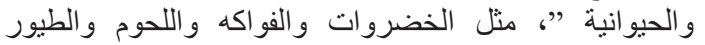

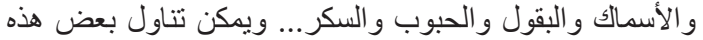

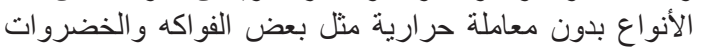

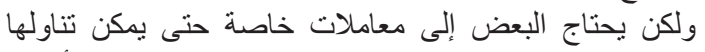

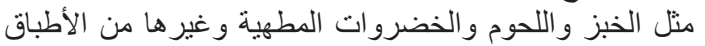
المطهية المختلفة وهذه تعرف بالأطعمة.

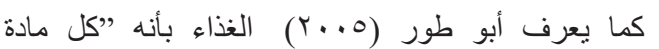

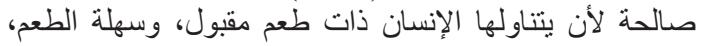

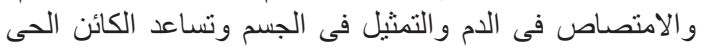

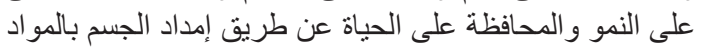

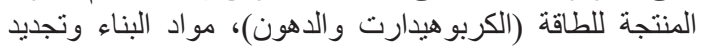

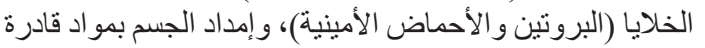

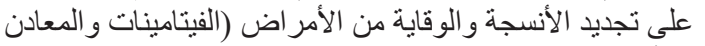

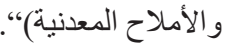

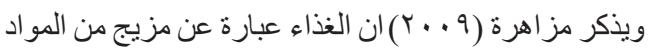

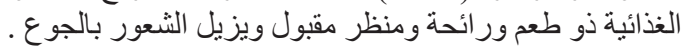

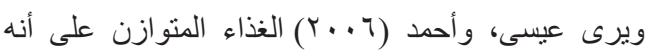

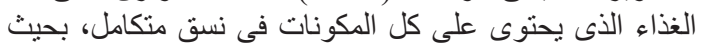

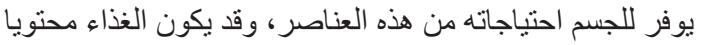

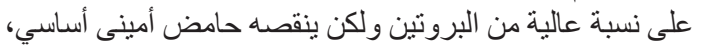

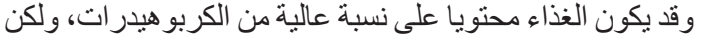

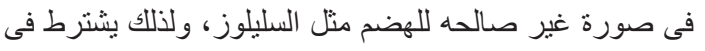

المقدمة

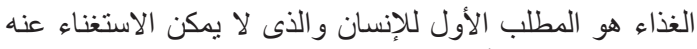

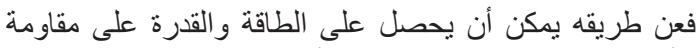

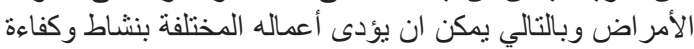

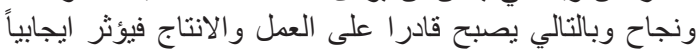

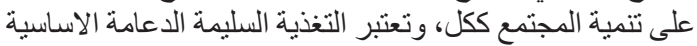

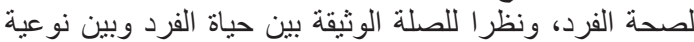

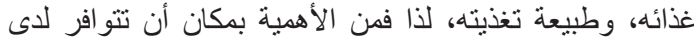

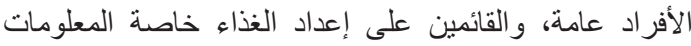

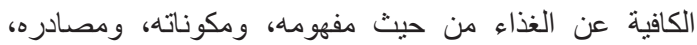

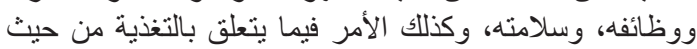

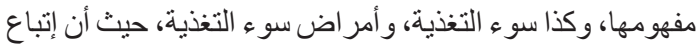

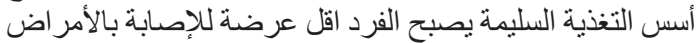

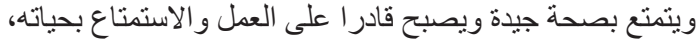

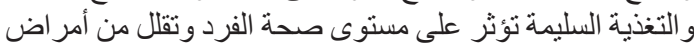

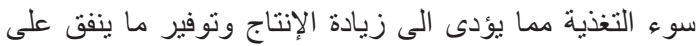

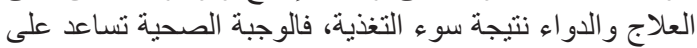

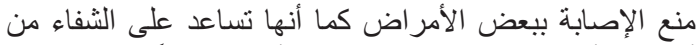

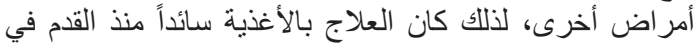

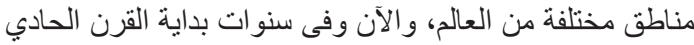

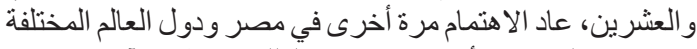

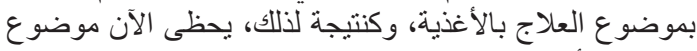

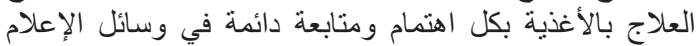

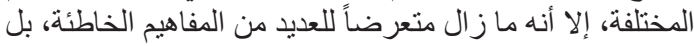

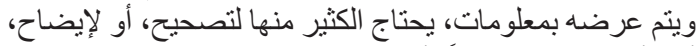

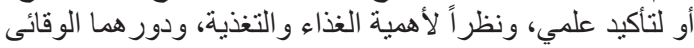
و العلاجى سوف نتناو لهم بشيء من لأهية التفيل. ولنيل.

الفصل الأول: الغذاء

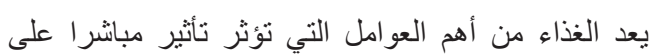

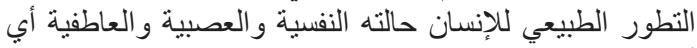
أنه يعطى الشكل العام لشخصية الإنسان (النمر ، . . . ب).

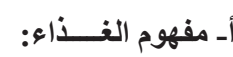

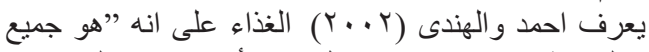

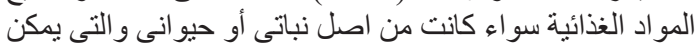

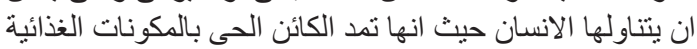

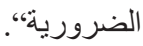


و الاجبان و الكبد و الكلى و السلامون و القشريات و البروتينات

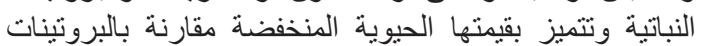

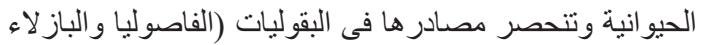

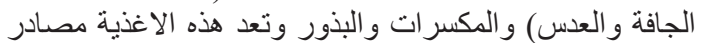

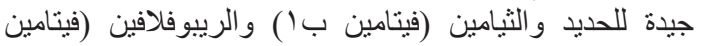

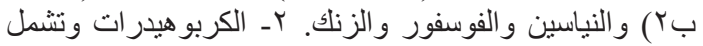

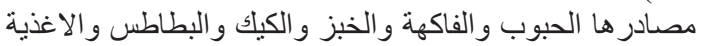

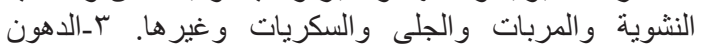

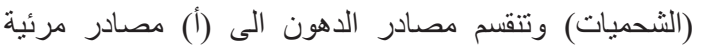

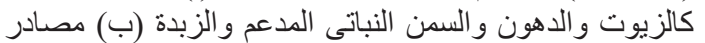

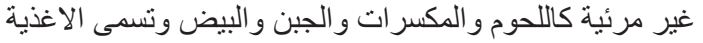

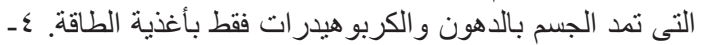

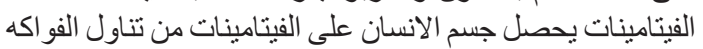

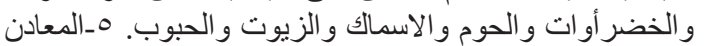

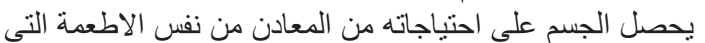

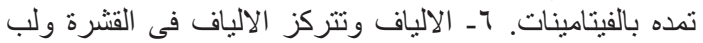

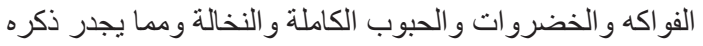

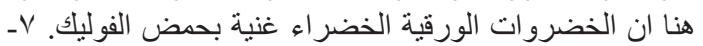

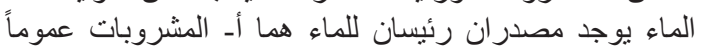

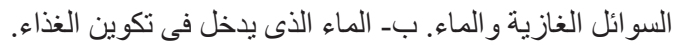

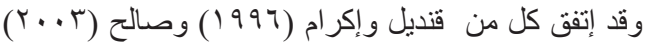

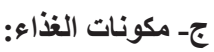

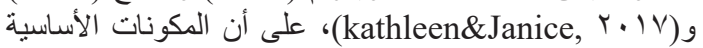

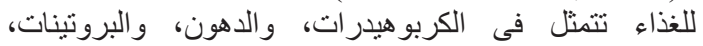
و الفيتامينات، و العناصر المعدنية، و الماء.

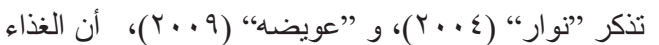

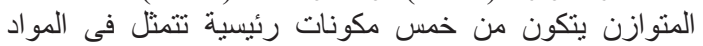

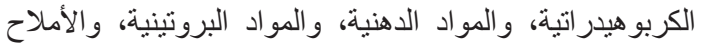

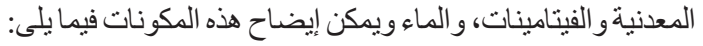

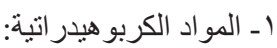

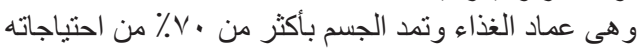

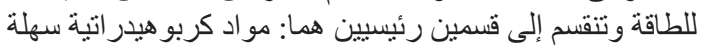

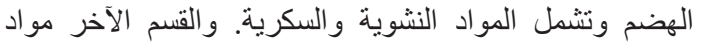

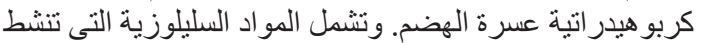

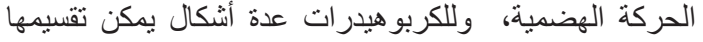

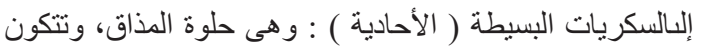

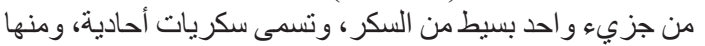

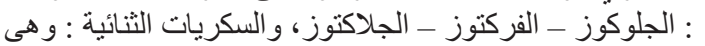

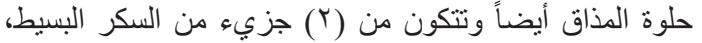

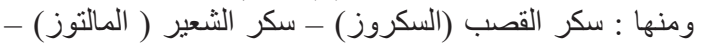

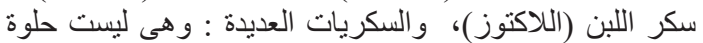

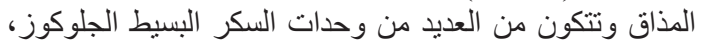

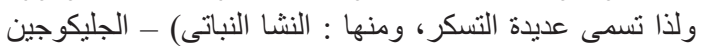

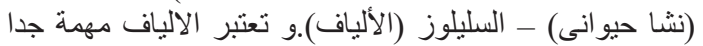

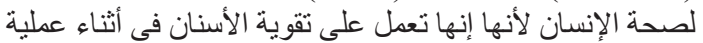

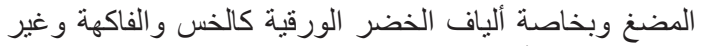

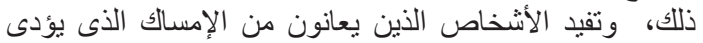

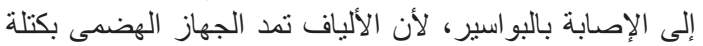

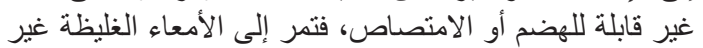

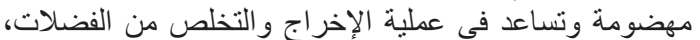

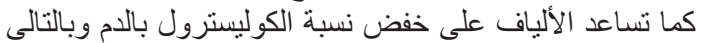
أمر اض القلب المرتبطة بها.
الغذاء أن يفى باحتياجات الجسم من كل هذه العناصر الضرورية لبنائه

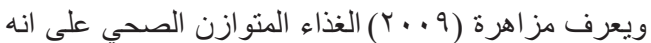

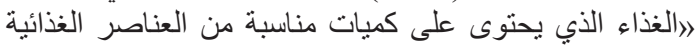

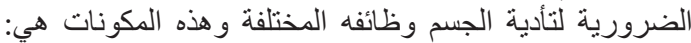

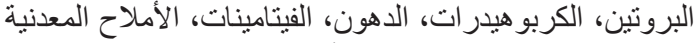

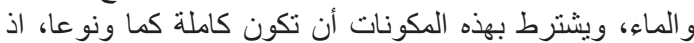

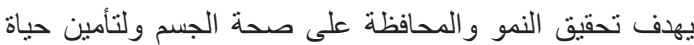
سليمة، وضمان مشاركة فعالة في الأسرة وفى المجتمعها.

فى حين تعرف بعض الدراسات الغذاء و الطعام على أنه

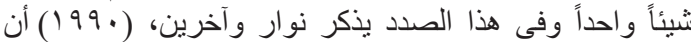

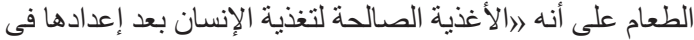

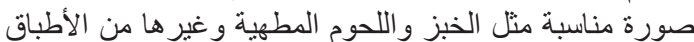

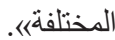

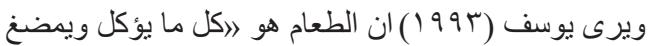
وينبغى الإشارة إلى أن كل غذاء طعام ولكن ليس كل طعام غذاء لهاء

ويشير مصطفى ودومة (990 190) إلى أن الطعام هو (اجميع

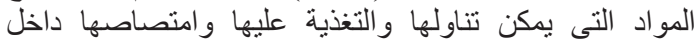

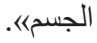

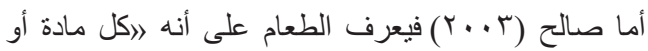

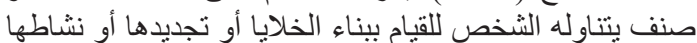

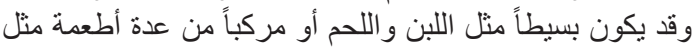

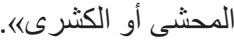

أما الغذاء الصحى فيقصد به الغذاء السليم الصالح للاستهلاك

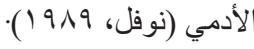

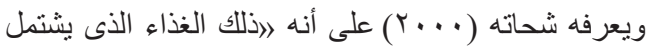

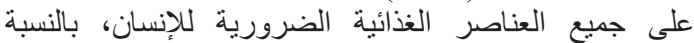
المنو ازنة التى لا ينتج عنها آثار سلبيةهان.

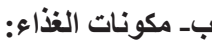

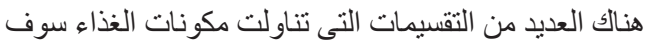

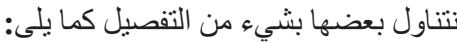

يقسم يوسف ( 999 (1) مكونات الغذاء من حيث ضروريتها

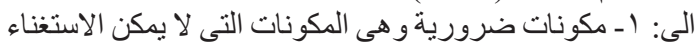

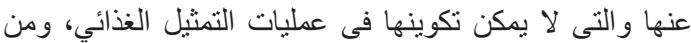

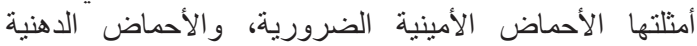

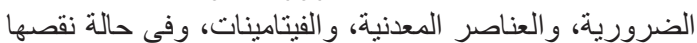

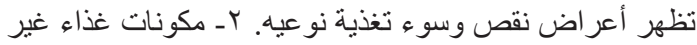

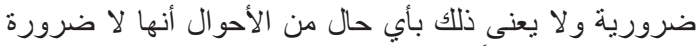

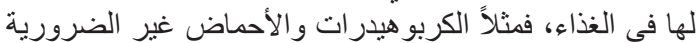

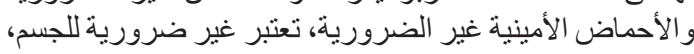

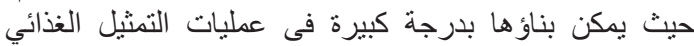
الوسيطة غير أنه يجب أن تكون هناك كئك كية كافية من المادة الخام

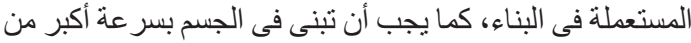

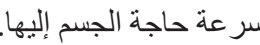

يذكر عويضة (999 (199) أن محتويات الوجبة الغذائية المتكاملة

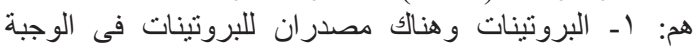

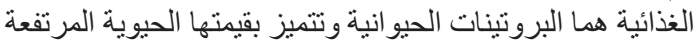

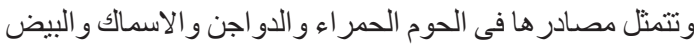

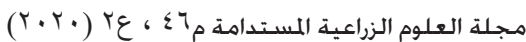


ـ و والنقل : كاللوز و البندق و الفستق و عين الجمل و الفول السوداني

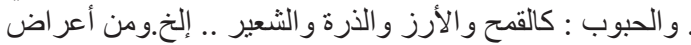

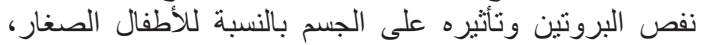

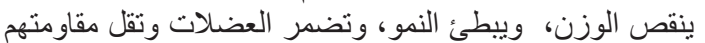

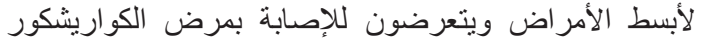
Kwashiorkor

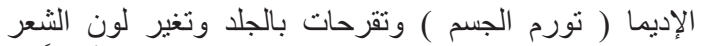

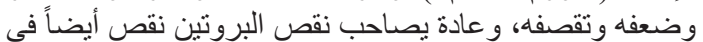

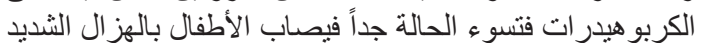

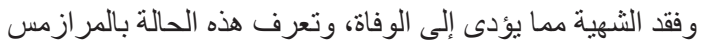
Miasmas ع ـالأملاح المعدنية و الفيتامينات:

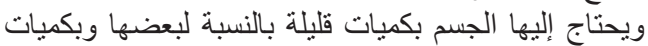

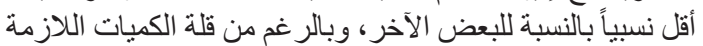

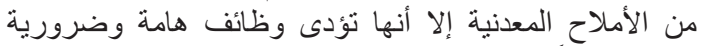

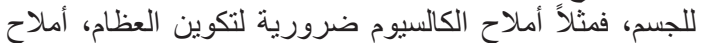

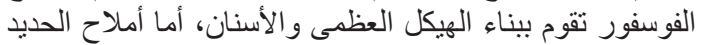

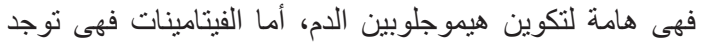

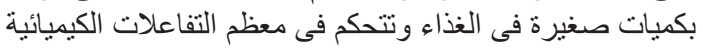

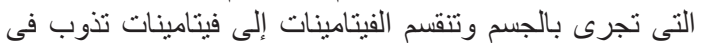
الدهن مثل فيتامينات (أ، د، ه، ك) و أخرى تذوب في الفى الماء مثل فتل

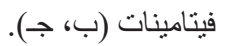

و هو ضرورى لجميع العمليات الحيوية داخل جسم الكائن

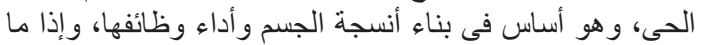

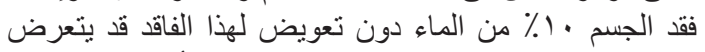

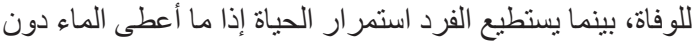

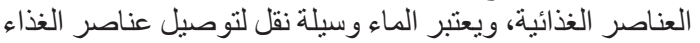

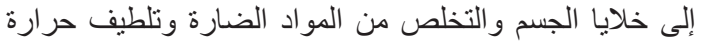

الجسم.

لد- مصادر مكونات الغذاء وفوائده:

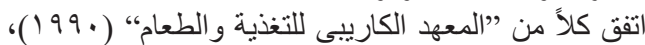

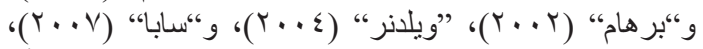

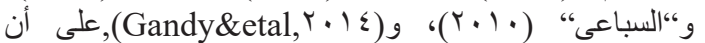
مصادر وفوائد العناصر الغذائية تتمثل فى:

1 ـ مصادر وفو ائد الكربو هيدرات:

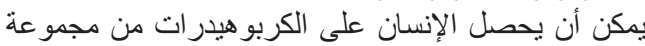

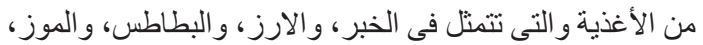

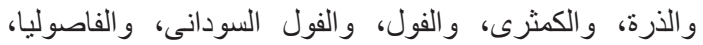

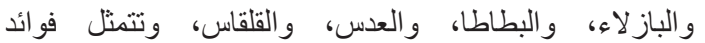

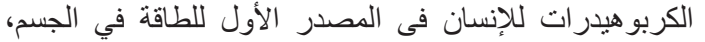

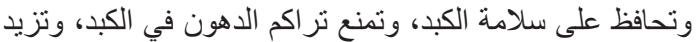

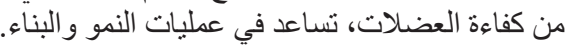

r - مصنادر وفو ائد البروتين: يمكن أن يحصل الإنسان على البرون البروتين من مجموعة من

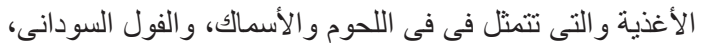

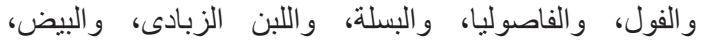

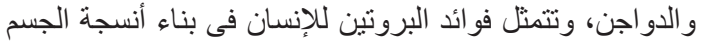

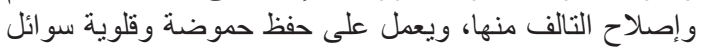

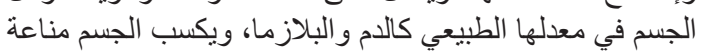
ضد المرض، ويحافظ على سلامة الأظافر و الجلد و الثُعر.

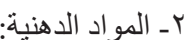

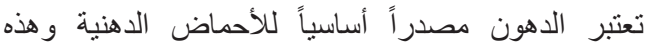

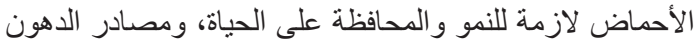

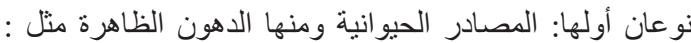

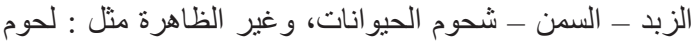

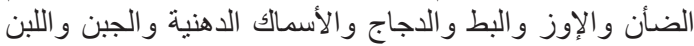

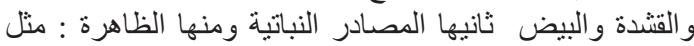

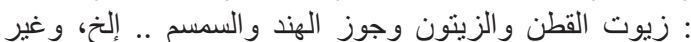
الظاهرة : كالمكسر ات و الكاكاو و الثيكو لاته، و الحلاوة الطحينية الطية

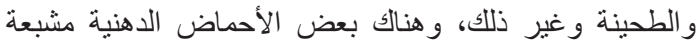

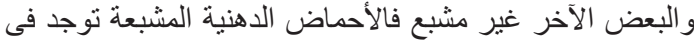

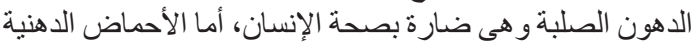

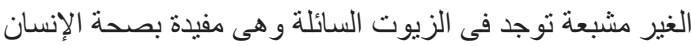

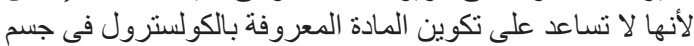

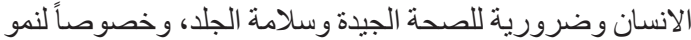

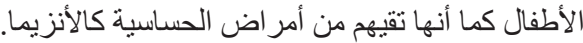

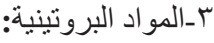
له الأهمية الأولى بين المواد الهين الغذائية لأنه يدخل فى تكوين

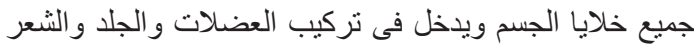

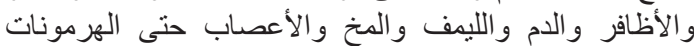

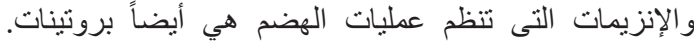

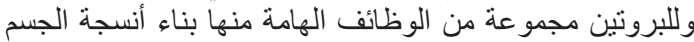

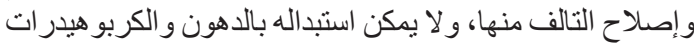

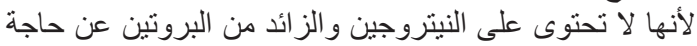

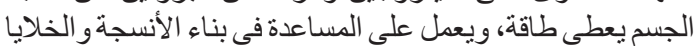

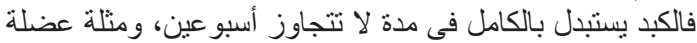

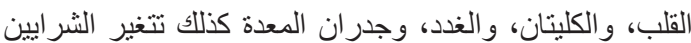

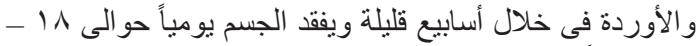

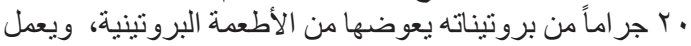

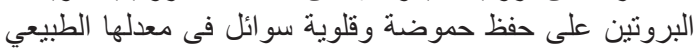

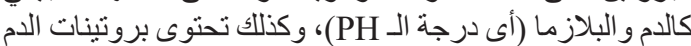

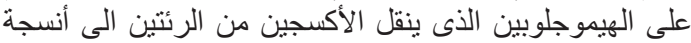

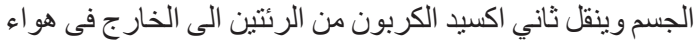

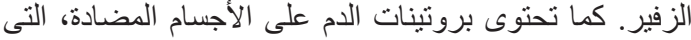

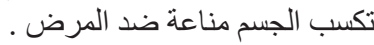

ولا يستفيد الجسم من بروتينات الأطعمة في عملية البناء

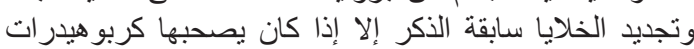

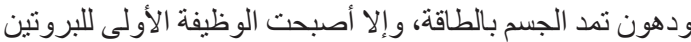

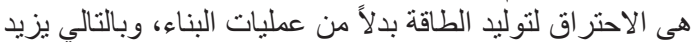

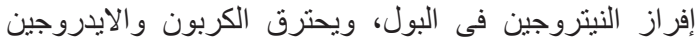

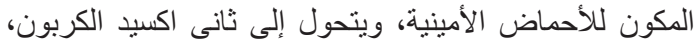

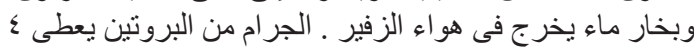

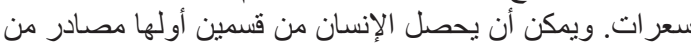

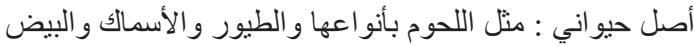

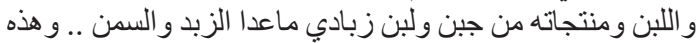
الأطعمة غنية بالبروتين، وتحتوى على جميع الاحماض بلى بلاض الأمينية

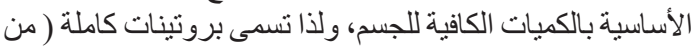

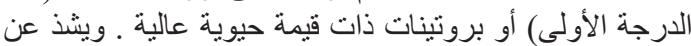

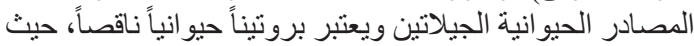

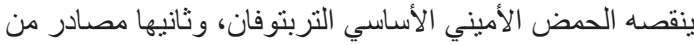

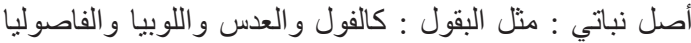

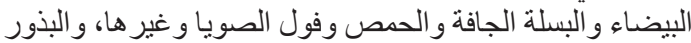

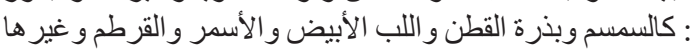


نباتية، وتتمثل فو ائد فيتامين (أ) للإنسان فى أنه هام لسلامة

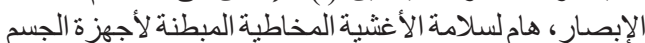
مثل (الجهاز الهضمي، الجهاز التنفسي، الجهاز التناسلي....)،

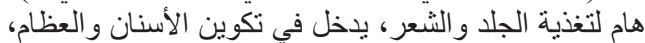

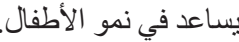

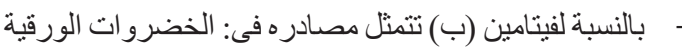

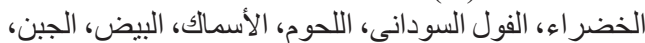

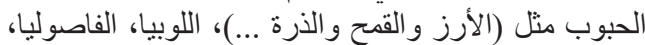

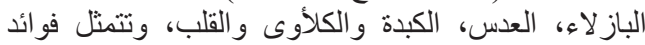

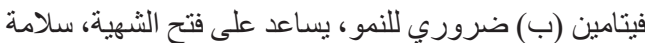

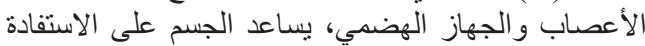

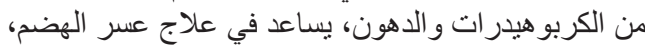

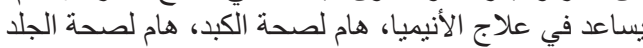

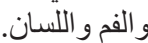

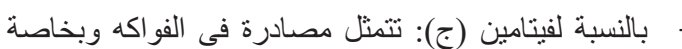

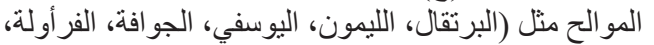

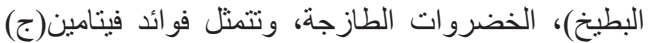

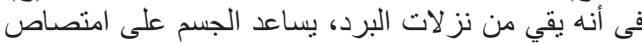

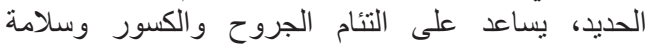

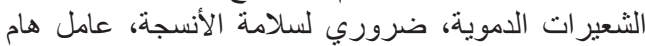

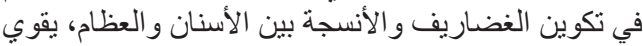

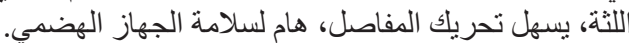

بالنسبة لفيتامين (د) تتمثل مصادرة فى: زيت كبد الحوت، الرئ،

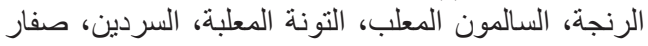

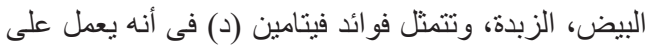

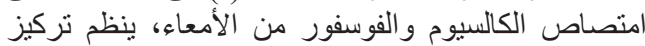
الكالسيوم و الفسفور في الدم و الأنسجة.

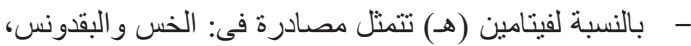

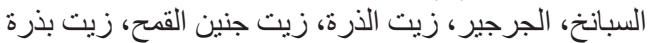

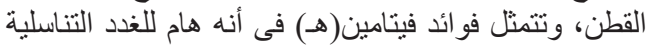

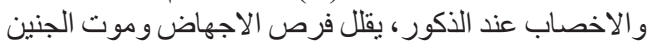

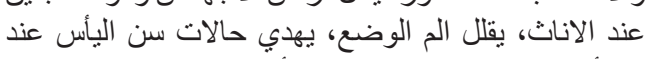

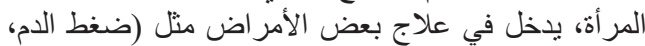

تصلب الثر ايين، ضعف العضلات).

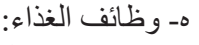

يذكر "مصطفى ودومه،" (1990) أهمية الغذاء تكمن فى الاتي:

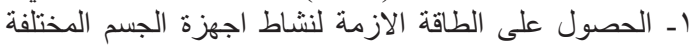

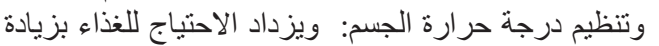

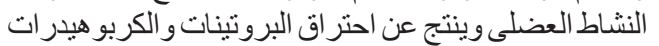

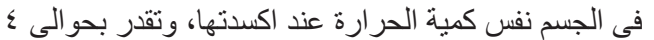

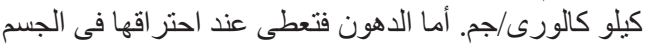

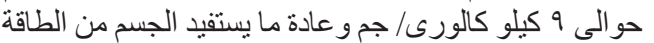

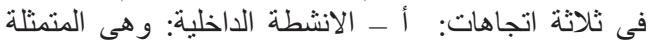

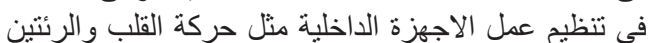
و الكليتين، وكذللك فى الدور ات الإخهة الخلية لتحويل المركبات تبعاً

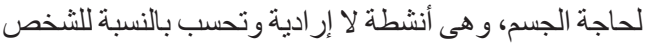

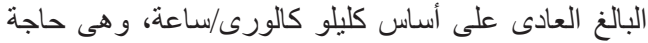

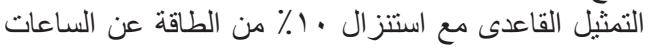

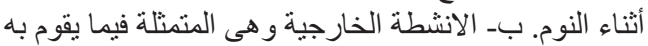

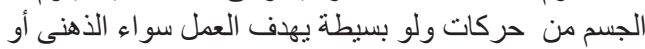

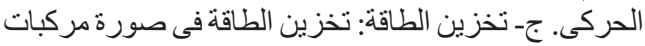
يمكن استخدامها عند الحاجة.
ب- مصادر وفو ائد الأملاح المعدنية:

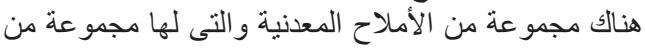

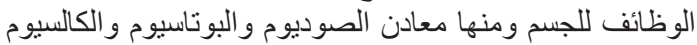

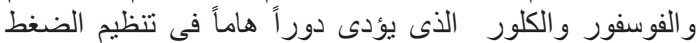

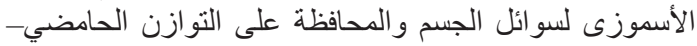

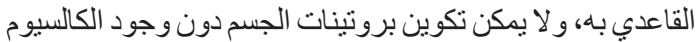

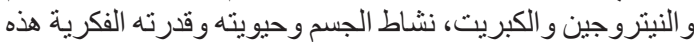

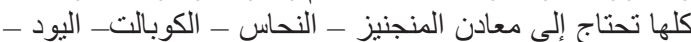

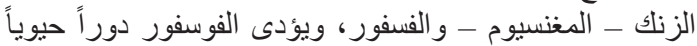

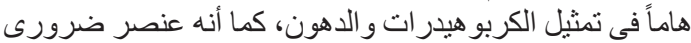

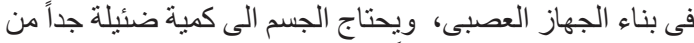

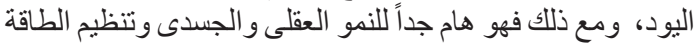

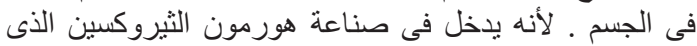

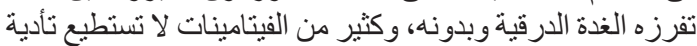

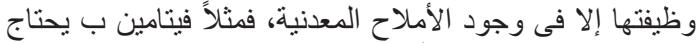

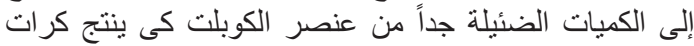

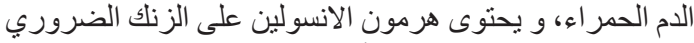

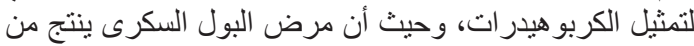

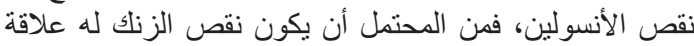

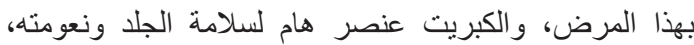

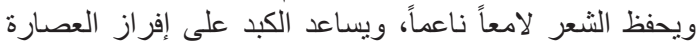

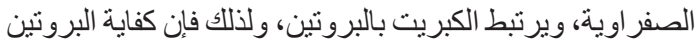

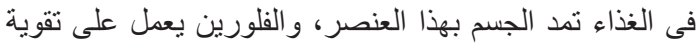

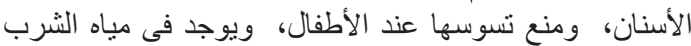

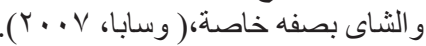

وسوف نركز فى هذه الدر اسة على أملاح الكالسيو و الحديد

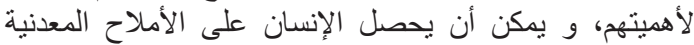

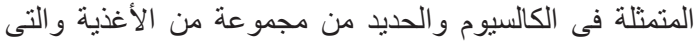

تتمنل فى:

- بالنسبة للكالسيوم تتمثل مصادره فى: اللبن و الجبن، القلقاس،

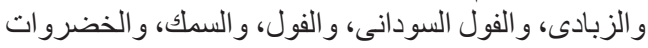

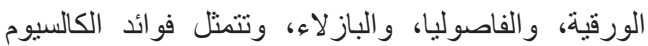

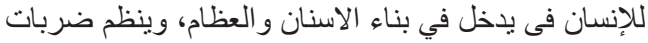

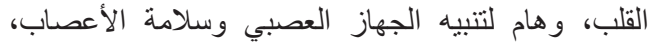

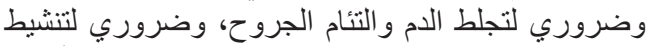

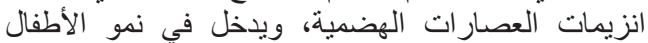

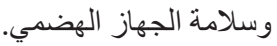

- أما بالنسبة للحديد تتمثل مصادره فى: الكبدة، والكلاوى،

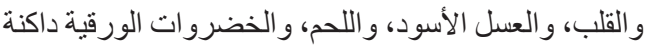

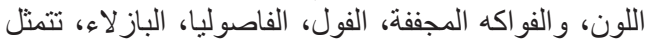

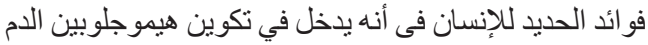

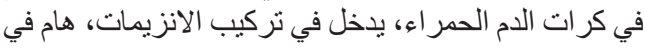

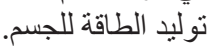

ع ـ مصنادر وفو ائد الفيتامينات:

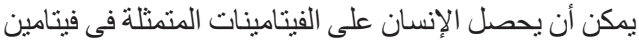

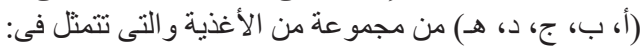

- - بالنسبة لفيتامين (أ) تتمثل مصادره فى: زيت الحوت، الكبد

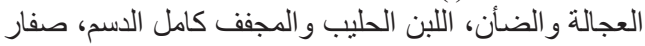

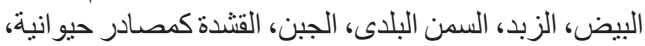

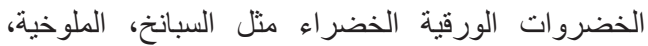

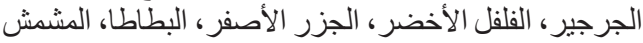

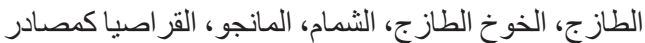

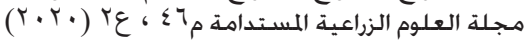




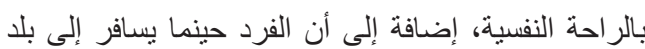

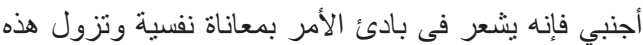

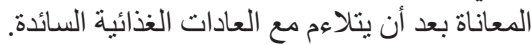
وـ مواصفات الغذاء المتوازن:

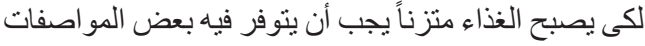

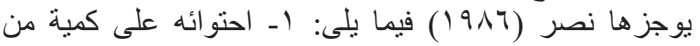

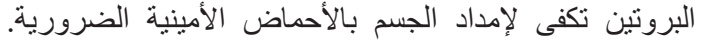

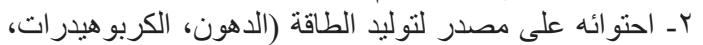

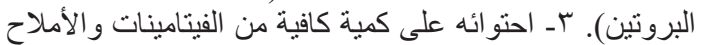

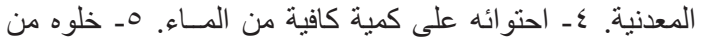

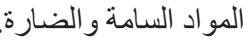

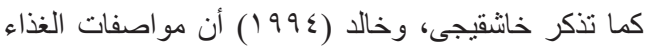

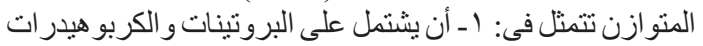

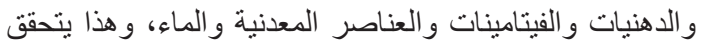

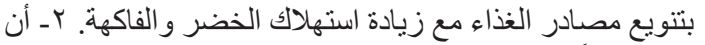

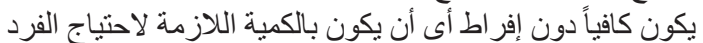

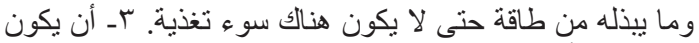

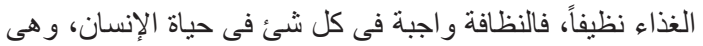

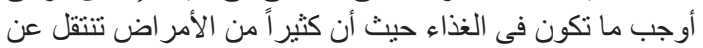

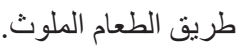

ويذكر محروس، ووهبه (1997) أن مواصفات الغذاء

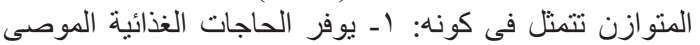

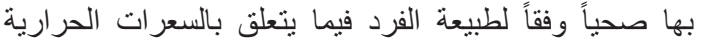

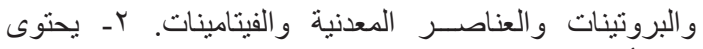

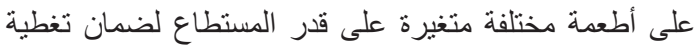

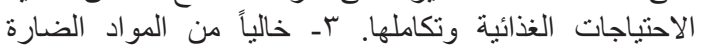

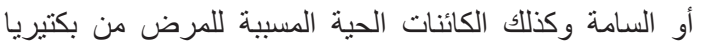

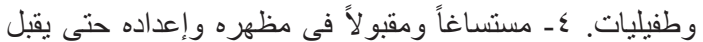

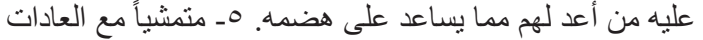
الغذائية للأفر اد و الجماعات على ألا يكون هذا على حساب قيمته

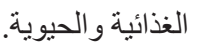

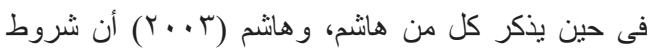

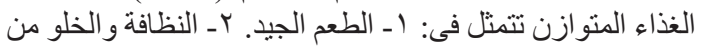

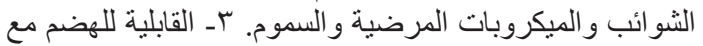

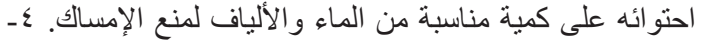

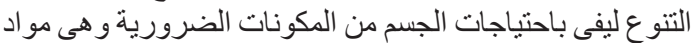

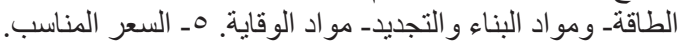

ز- الممارسات المتعلقة بعمليات طهي وإعداد الغذاء:

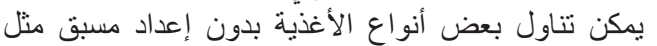

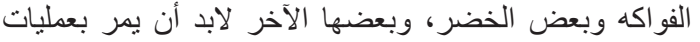

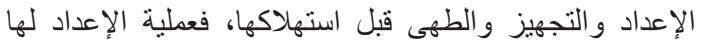

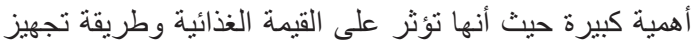

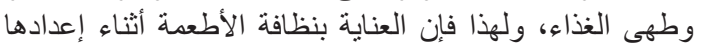

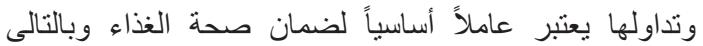
صحة الأسرة وكذللك ينبغى مر اعاة الأسس السليمة أثناء إعدادها

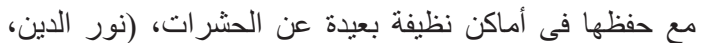
.( r..

يعرف نوار (9V7 ( ) )طهي الغذاء على انه "معاملة الأغذية

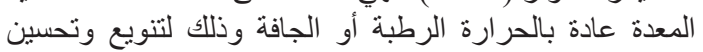
مظهر وطعم ور ائحة كثير من المواد الد الغذائية"،

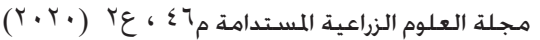

r ب بناء أنسجة الجسم وتعويض الخلايا التي تموت: ولهذا فإن

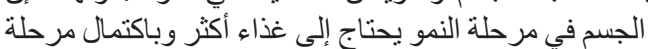

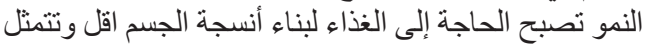

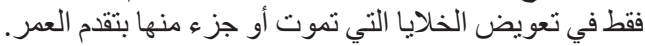
ويحدد "الجارحى" (997 (1) وظائف الغذاء للإنسان فى أنه وسيلة لإمداد جسم الإنسان بكل من: الطئ

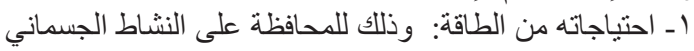

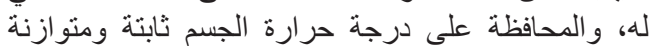
وكذلك تنظيم أداء أجهزة الجسم المختلفة.

rـ الاحتباجات من البروتين: حيث تلعب البروتينات دوراً حيوياً

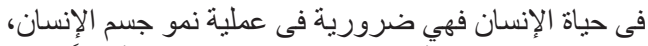

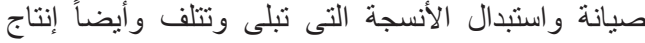

الهرمونات وكذلك الهيموجلوبين علاوة على إنتاج الطاقة.

rـ الاحتياجات من الفيتامينات و العناصر المعدنية: حيث أن لها

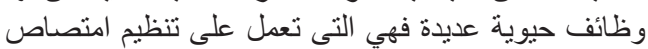

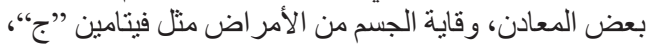

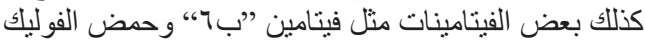

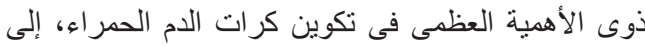

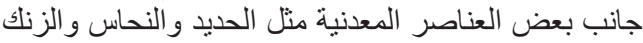

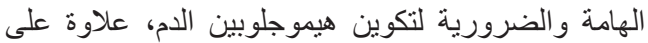

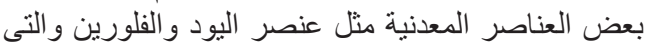

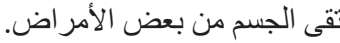

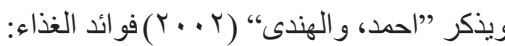

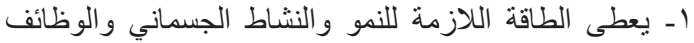

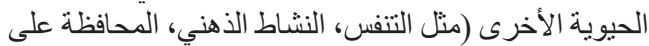

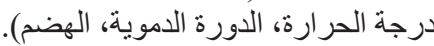

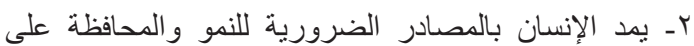

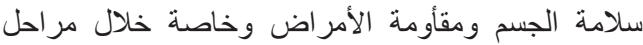

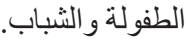

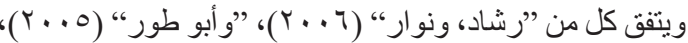

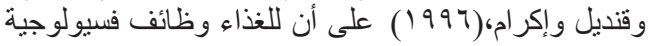

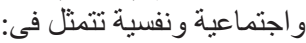

1ـ الوظائف الفسيولوجية للغذاء وتتمثل في: إن الغذاء بمد

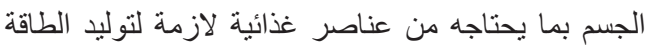

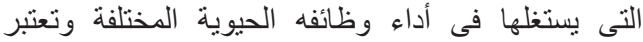

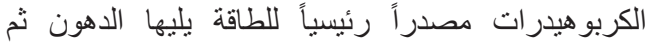

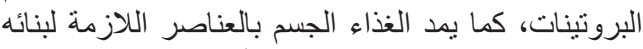

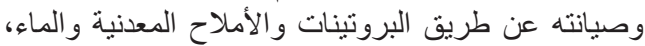

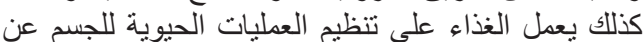

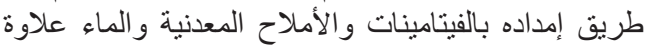
على الأحماض الأساسية والبروتينات.

r- الوظائف الاجتماعية للغذاء وتتلخص في: تعتبر حفلات

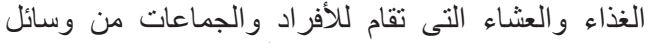

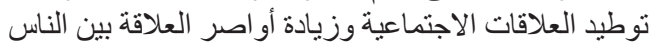

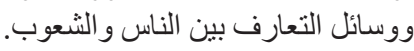

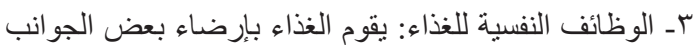

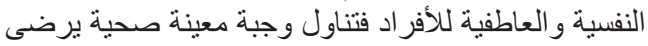

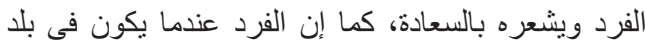

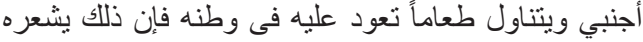


من مرة وذللك لقتل الجر اثيم و الميكروبات، ويفضل تدفئة اللبن

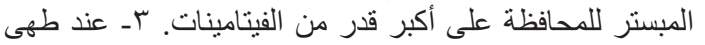

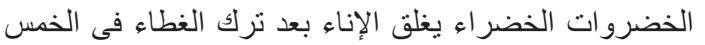

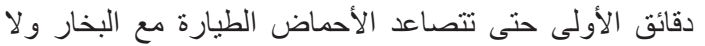

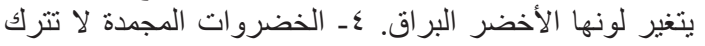

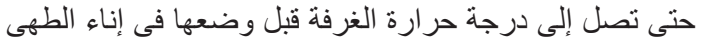

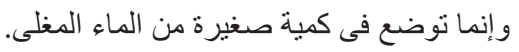

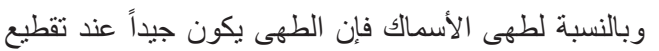

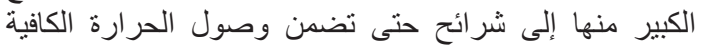

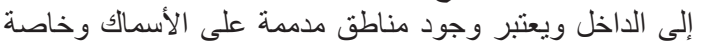

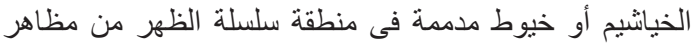

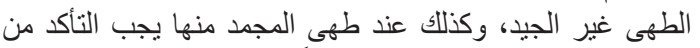

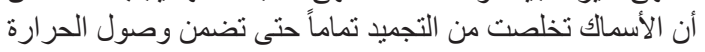

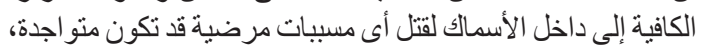

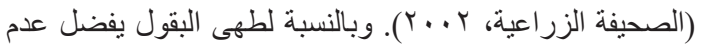

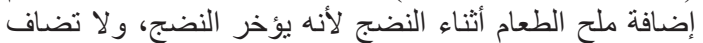

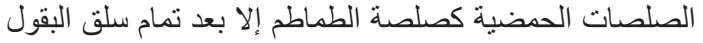

لأن الوسط الحمضى يعوق إنضاج البقول، (عيسى وآخرون).

و عن بعض الإرشادات التى تتبع للحفاظ على الغذاء أثناء

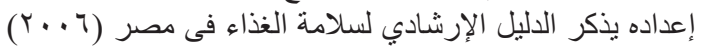

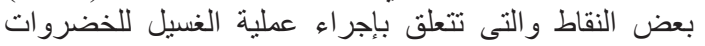
و الفاكهة و التي يمكن ايجاز ها فيما يلى بلى

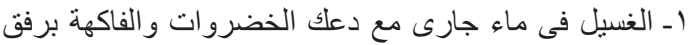
بالأيدي لإز الة الأوساخ واري الميكروبات المتو اجدة على السطح.

r- غسيل الخضروات و الفاكهة قبل التقديم وليس قبل التخزين

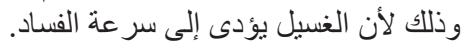

rـ ـ تغنل الثمار قبل التقطيع.

ــ المنتج الموجود في صورة جلد سميك مثل الجزر و البطاطس و الثمام يفضل دعكها بفرشاة.

هـ عادة يتم غسيل الكوسة أو الثمام لو لم تؤكل القشرة الخارجية

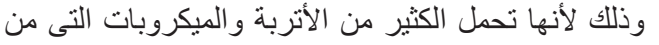

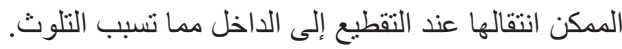

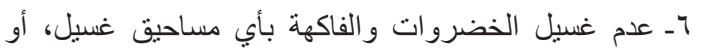

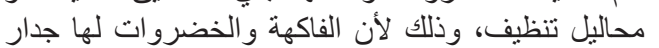

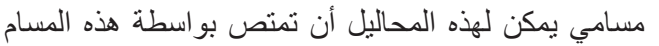
إلى داخل المنتج، وتصبح مصدر من مصادر التلوث.

V- التقنشير الجيد للفو اكه وذلك لتجنب المبيدات الحشرية.

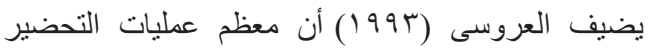

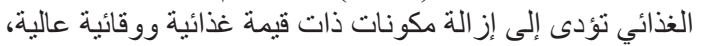

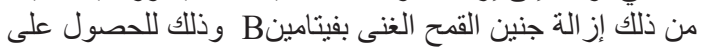

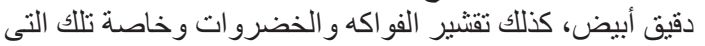

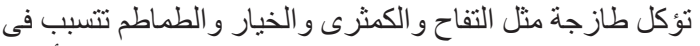

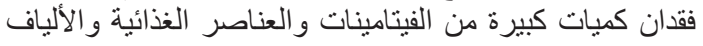

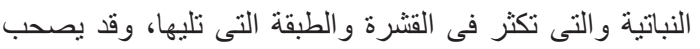

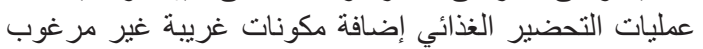

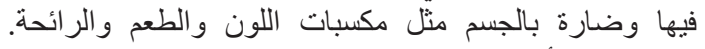

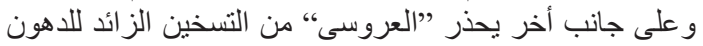

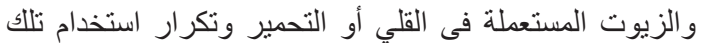

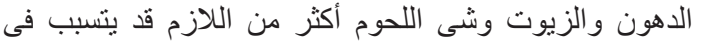

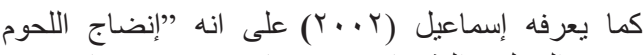

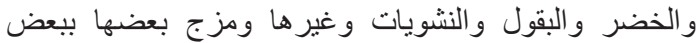

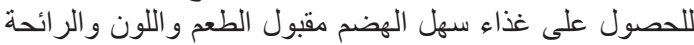
ويتحقق ذلك بالطهى المتقن السليم"

وللطهى مز ايا يوجز ها موتر ام (910 1 ) فى: ( - جعل الطعام

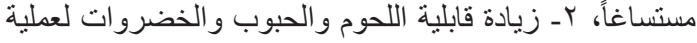

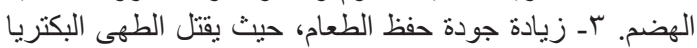

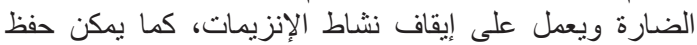

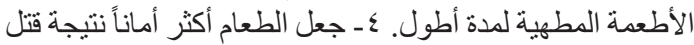

البكتيريا و الطفيليات وبيضها.

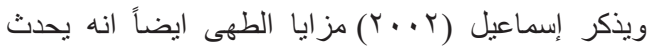

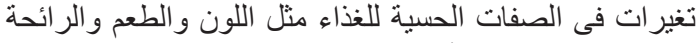

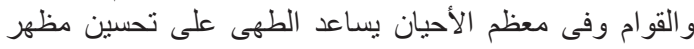

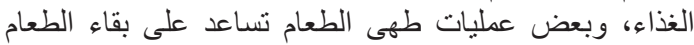

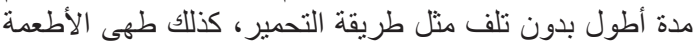

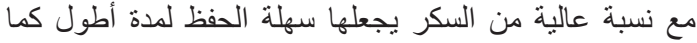

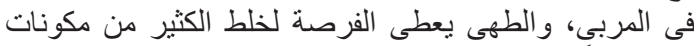

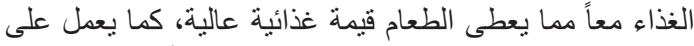

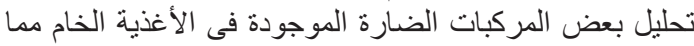

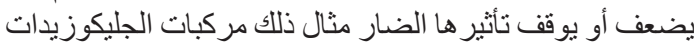

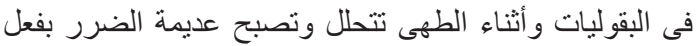

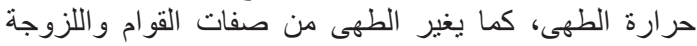

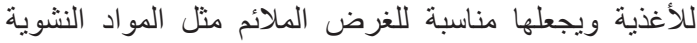

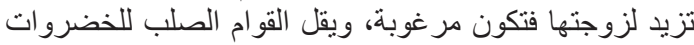

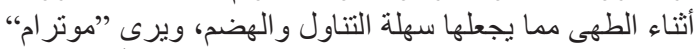

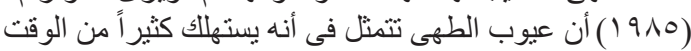

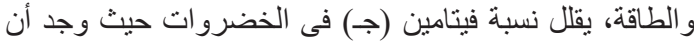

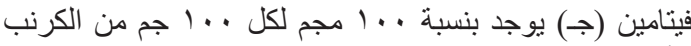

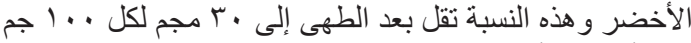

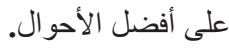

ويؤثر الطهى على القيمة الغذائية فيسبب فقد بعض العناصر

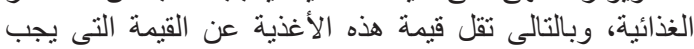

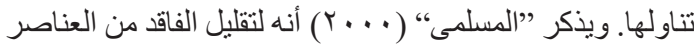

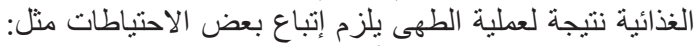

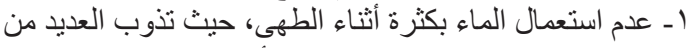

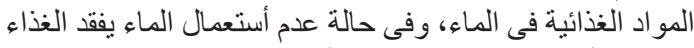

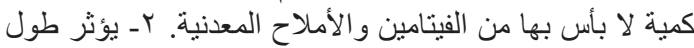

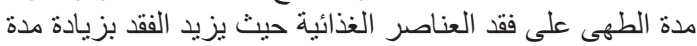

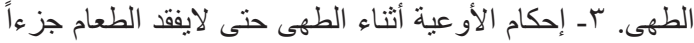

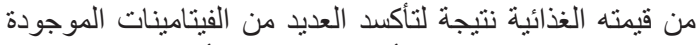

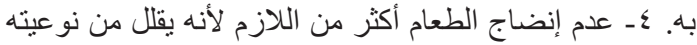

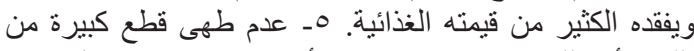

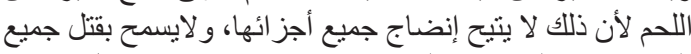

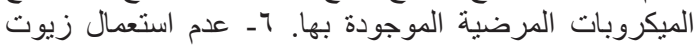

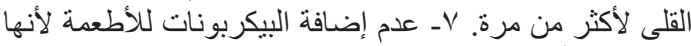

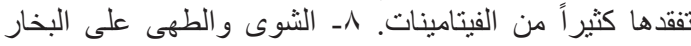

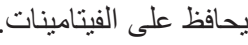

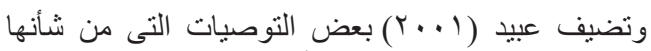

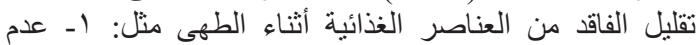

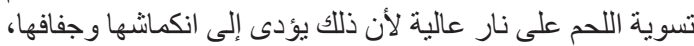

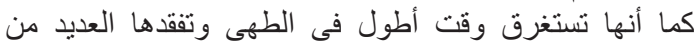

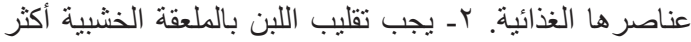

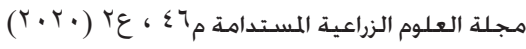




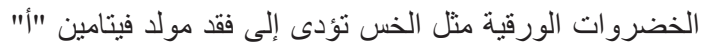

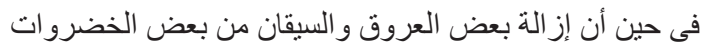

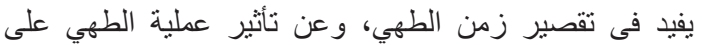

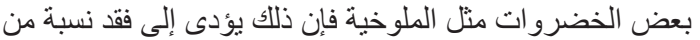

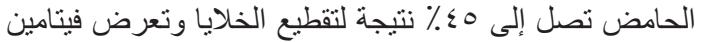

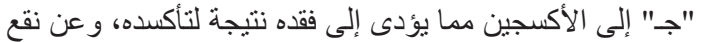

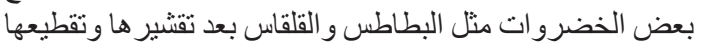

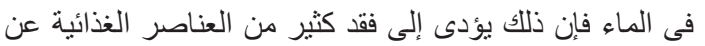

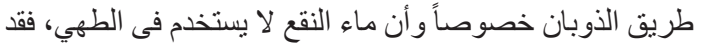

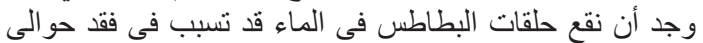

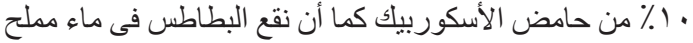

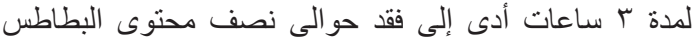

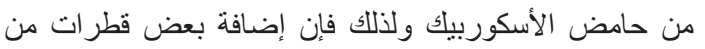

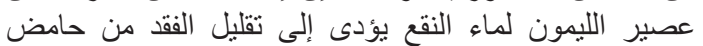

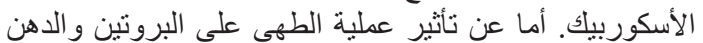

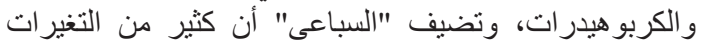

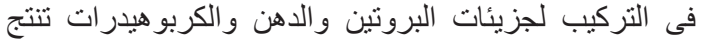

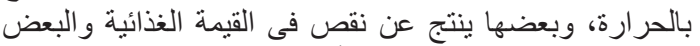

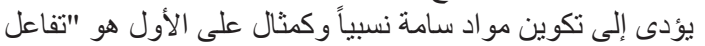

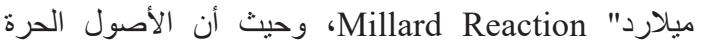
للأحماض الأمينية تتفاعل مع التسمين مع السكريات المختزلة النية

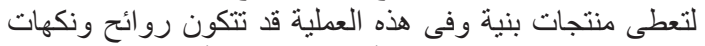

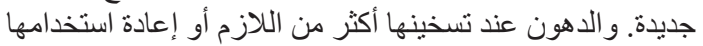

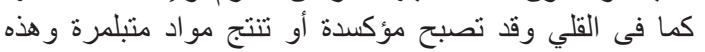

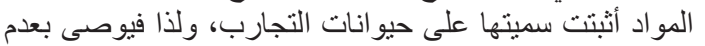

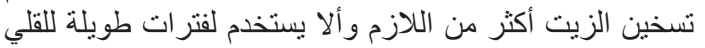

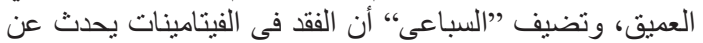

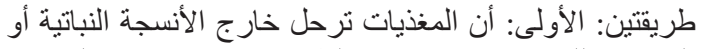

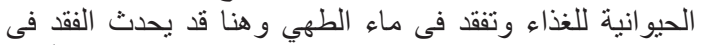

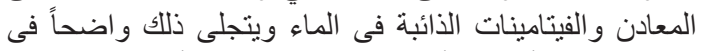

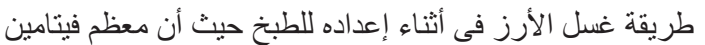

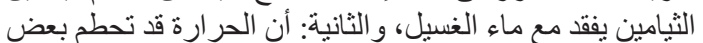

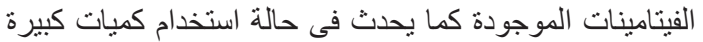

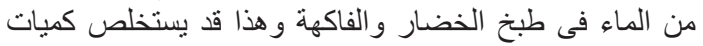

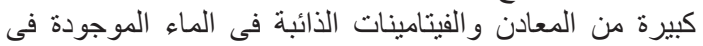

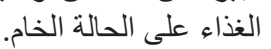

ح- سوء التغذية:

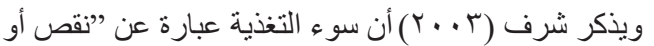

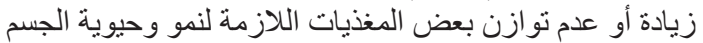

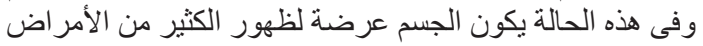

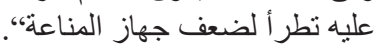

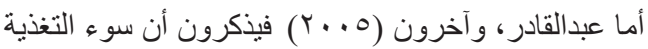

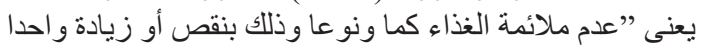

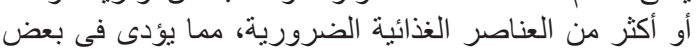

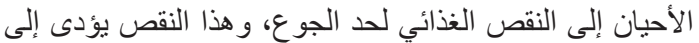

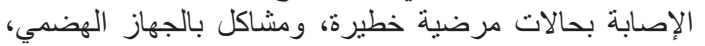

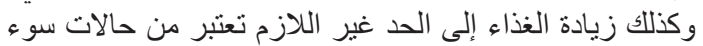

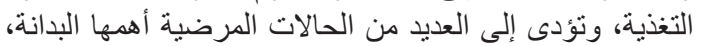

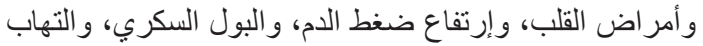

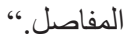

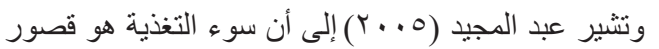
الغذاء فى واحد أو اكثر من العناصر الغذائية.
تكوين مو اد مسرطنة. كذلك فإن رفع درجة حر ارة الطهي ينتج

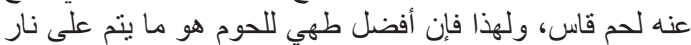

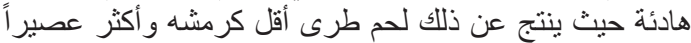
و وأقل ضرر اً على حئ الصحة.

وتذكر منظمة الاغذية و الزر اعة ( ؟ 99 ( ) انه تحت الظروف

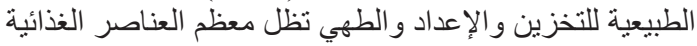

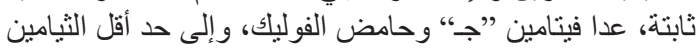

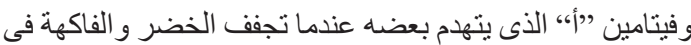

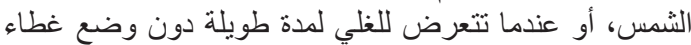

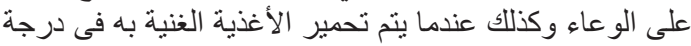

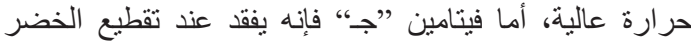

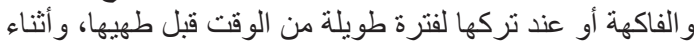

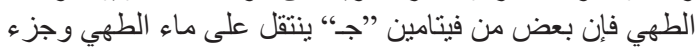

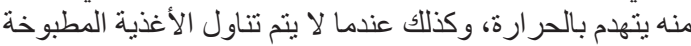

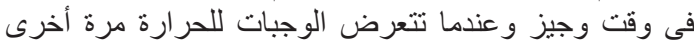

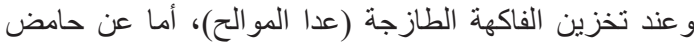

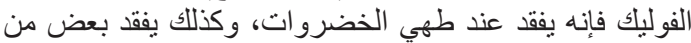

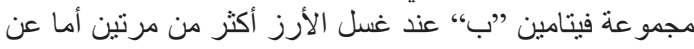

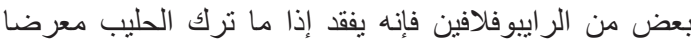

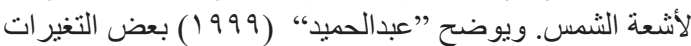
التى تحدث على الغذاء عند إعداده فيما يلى لئى

1- بحدث نقص فى الأحماض الأمينية (ليسين - ميثونين -

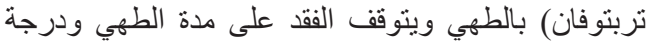
حر ارته، لذا لا ينبغى الإفر اط فيى التسخين الثديد لمدة طويلة.

$$
\text { r- يؤدى التحمير إلى نقص طر اوة اللحوم. }
$$

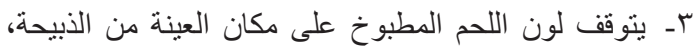

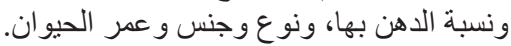

ع- إطالة فترة التخزين تؤدى إلى تحلل البروتين بواسطة

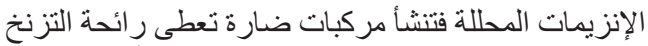

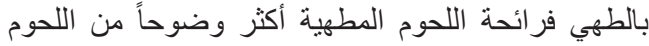
الطازجة.

0ـ الطعم فى اللحوم يتوقف على نوع و عمر الحيوان، ونظام

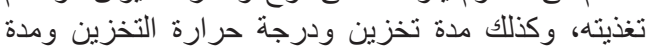

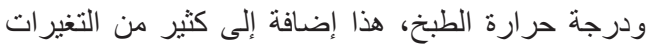

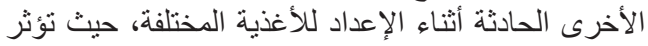

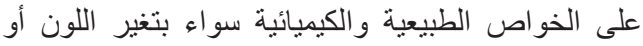

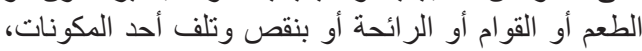

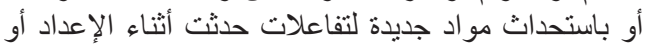

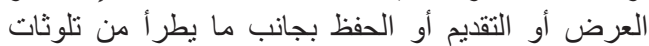

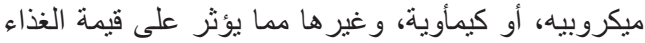
وصلاحيته للاستهلاك.

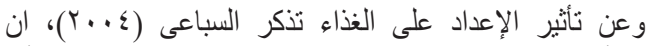

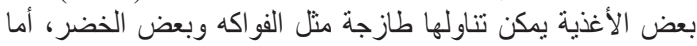

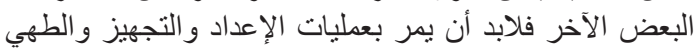

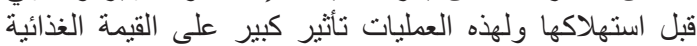

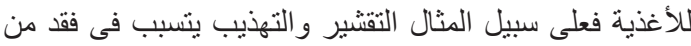

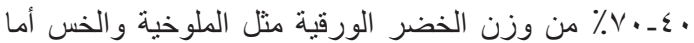

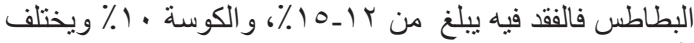

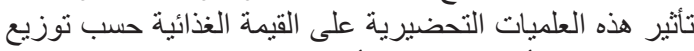

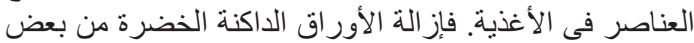

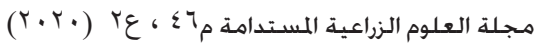


ويتناول عبد الرحمن ( •1999) الأمراض الناتجة عن سوء

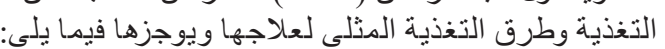

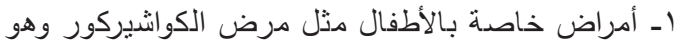

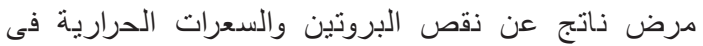

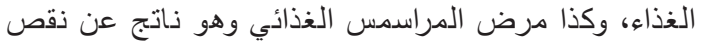

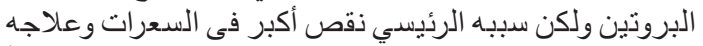

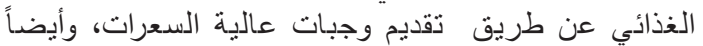

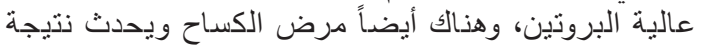

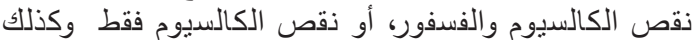

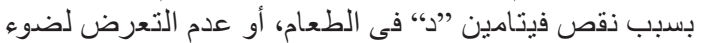

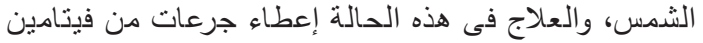

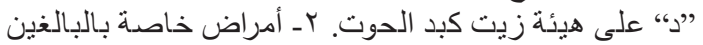

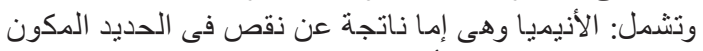

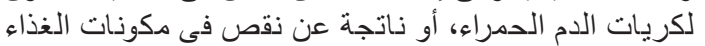

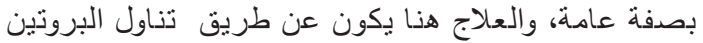

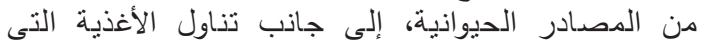

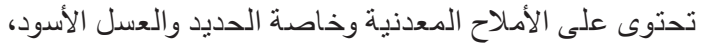

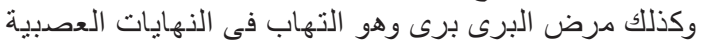

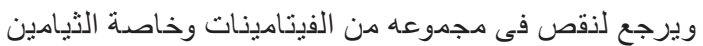

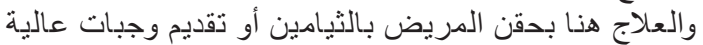

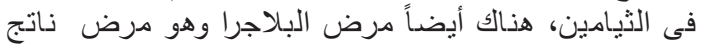

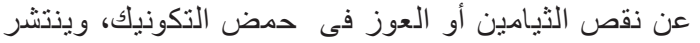

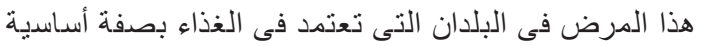

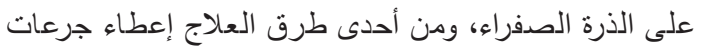

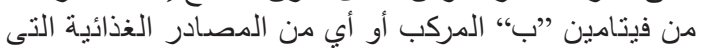

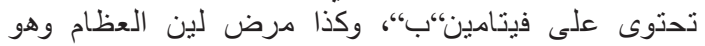

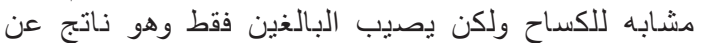

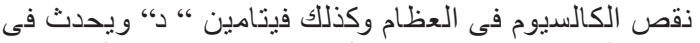

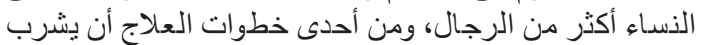

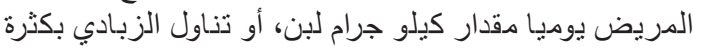

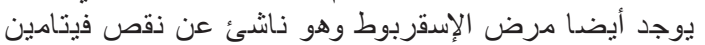

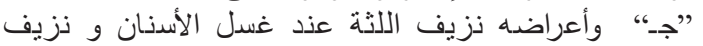

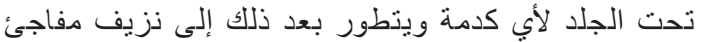

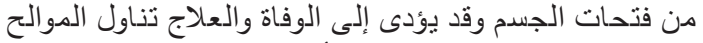

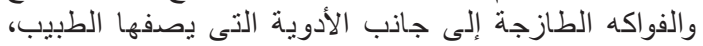

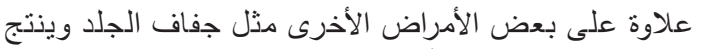

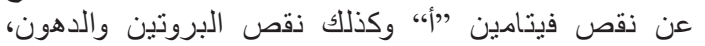

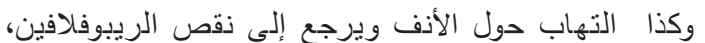

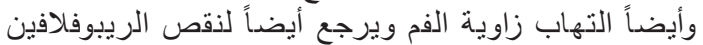

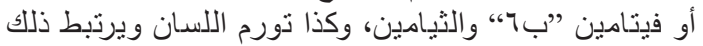

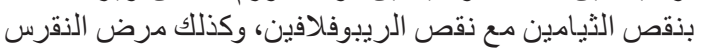

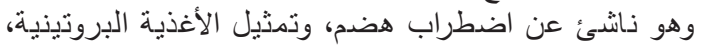

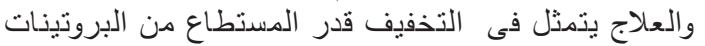

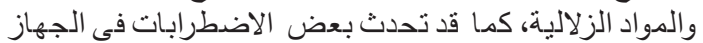

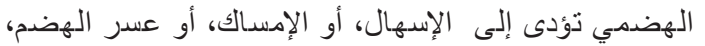

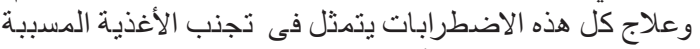

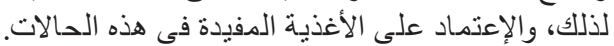

أما رشاد، وذوار (1991) فيتناولا أمراض سدوء التغذية

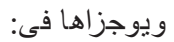

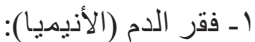

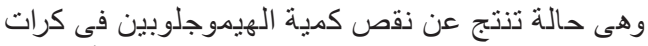
الدم الحمراء، فتقل مقدرة تلك الكرات على على حمل الكد الأكسجين

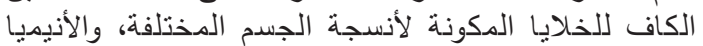

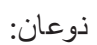

طـ أسباب سوء التغذية:

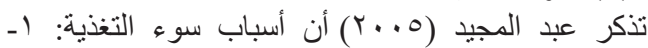

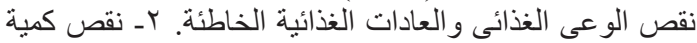

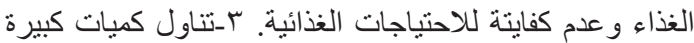

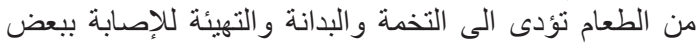

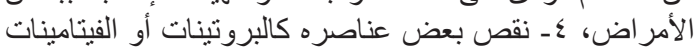

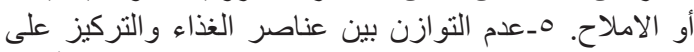

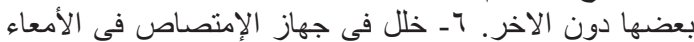
نتيجة لأمر اض الأمعاء أو وجود الطفيليات فى الأمعاء.

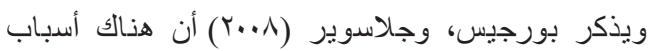

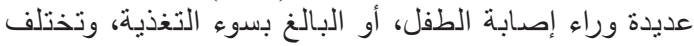

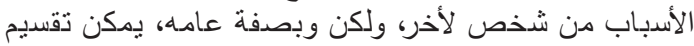

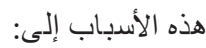

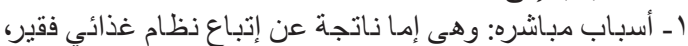

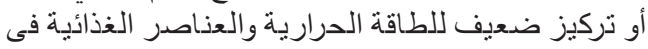

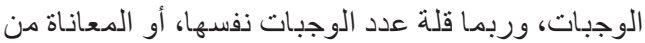
مرض. rـ أسباب ضدمنيه: وتثدل القصدور فى كمية الغذاء الأسدرى،

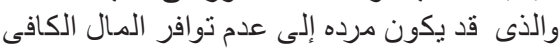

لإحضار الطعام، أو سوء تخزين، وحفظ الغذاء، وكذلك الظروف المعيشية السيئة مثل ماء غئ غير كافي ودي

قصدر فى مسذوى النظافة أو تزاحم سكاني فى المنازل.

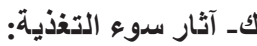

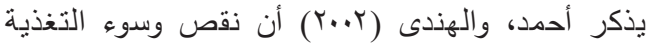

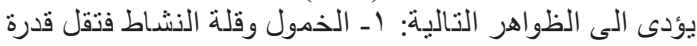

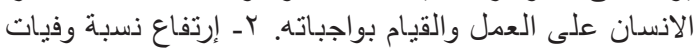

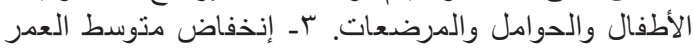

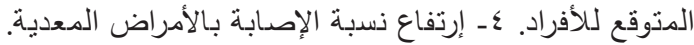

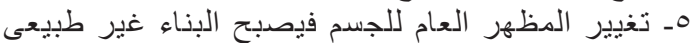

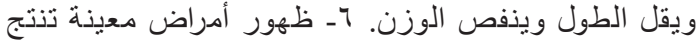
مباشرة عن نقص عنصر أو أكثر من العناصدر الغذائية.

ل- أمراض سدوء التغذية:

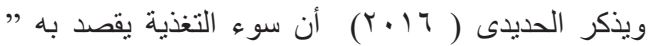

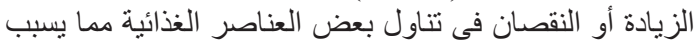

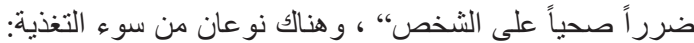

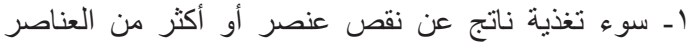

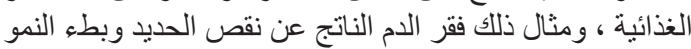

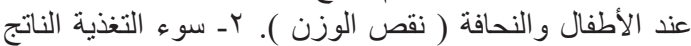

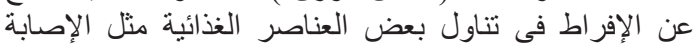

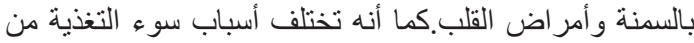

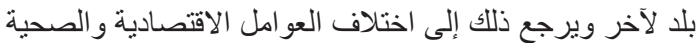

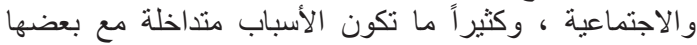

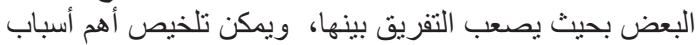

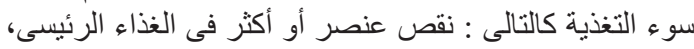

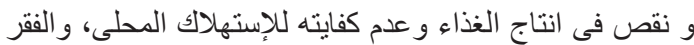

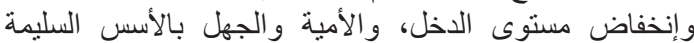

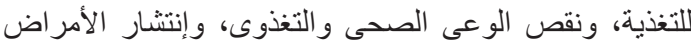

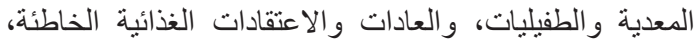

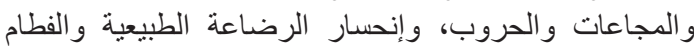

المبكر.

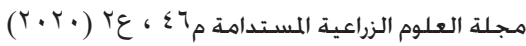


أوقد نذشأ النحافة بسبب عدم قدرة الجسم على تمثيل الغذاء

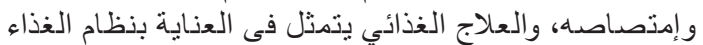

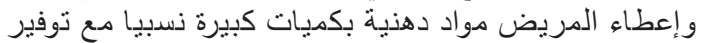

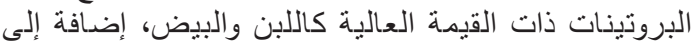

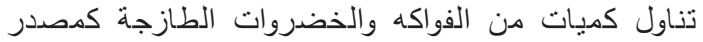
للفيتامينات والأملاح المعدنية بالإضدافة إلى علاج مسدبيات النحافة.

م- نماذج لبعض العادات الغذائية الخاطئة التى تؤدى الى لى التى

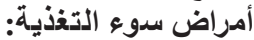

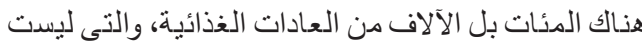

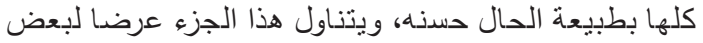

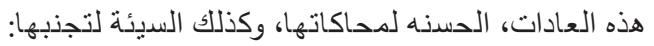

بعرض المخللاتى (1917) بعضداً من هذه العادات

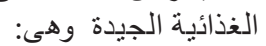

ا- عدد الوجبات فى اليوم: وهى تختلف من مكان لآخر

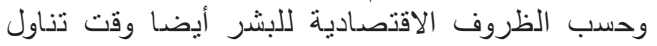

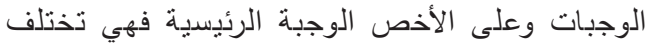
أيضدا من مكان لآخر.

r- انتظام تناول الوجبات: وهو يعد سلوك جيد من وجهة نظر الطباخين وأصحاب المطاعم ولكن وجهاب ولئة نظر الإنسان

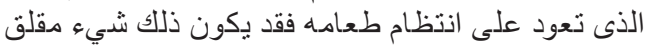

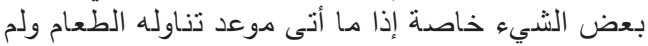

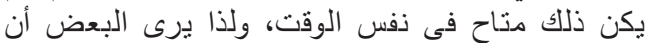

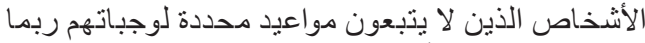
يكوذون أحسن حظاً من هؤلاء المنتظمون.

rـ الشرب عند الوجبات: يصفه البعض أن الثرب مع الأكل

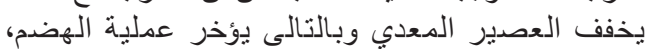

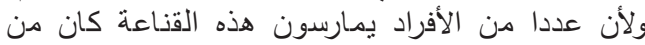

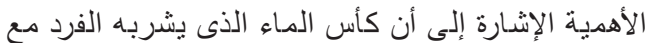

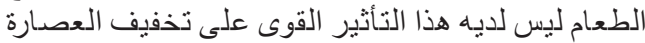

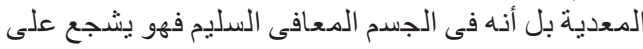

إفرازها.

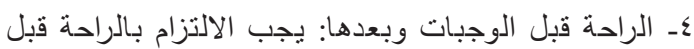

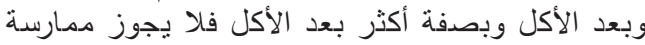

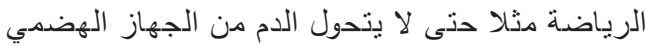
إلى الجهاز العضدهي.

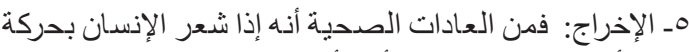

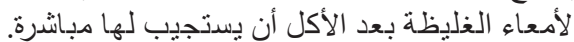

أما علوى ( •199) نتناول بعض العادات الغذائية السيئة، وبعض السبل لتصديحها:

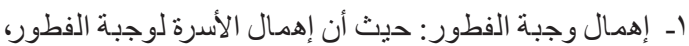

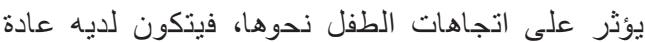

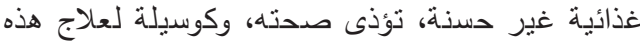

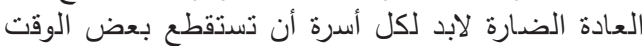

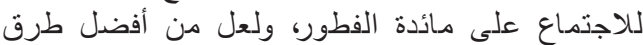
الوصدول لذلك هو الذوم المبكر والاستيقاظ الدطول المبكر.

r- رفض ذوع معين من الطعام: وهى بالطبع عادة غذائية

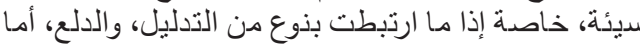

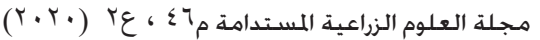

الذوع الأول: وهو أنيميا نقص الحديد وترجع إلى نقص إنص

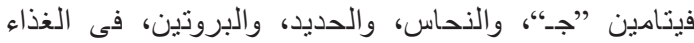

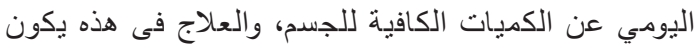

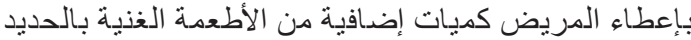

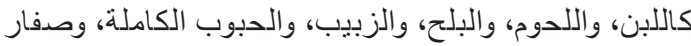

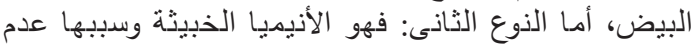

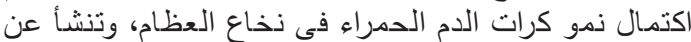

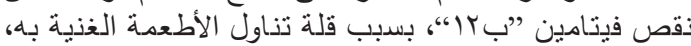

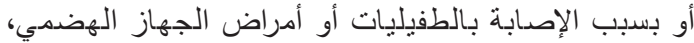

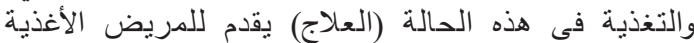

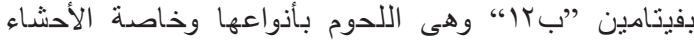

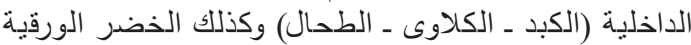

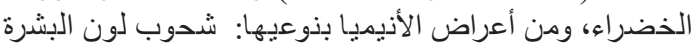

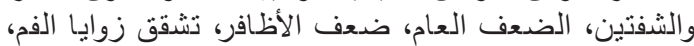
صدوبة التذفس، سدوء الهضعدم.

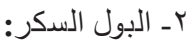

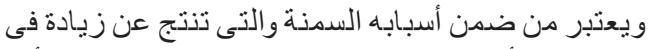

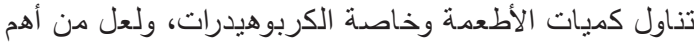

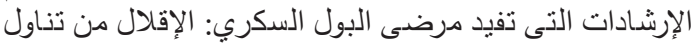

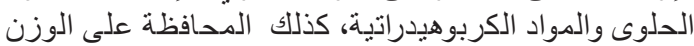
الطبيعي وذلك عن طريق إتباع نظام غذائي صحي. rـ تصدلب الثرايين:

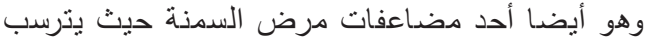

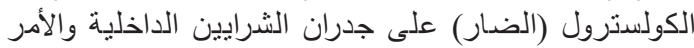

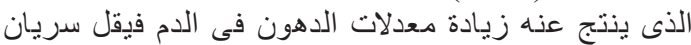

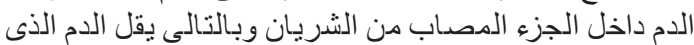
يصدل إلى عضدلة القلب حاملا إليها الغذاء والأكسجين.

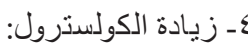

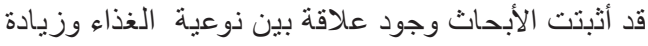

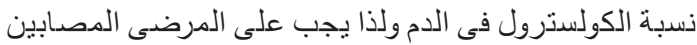

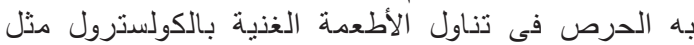

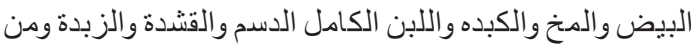

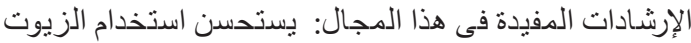

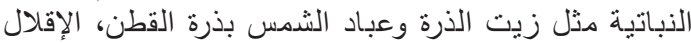

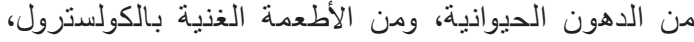

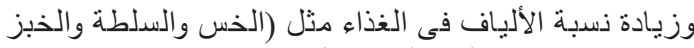

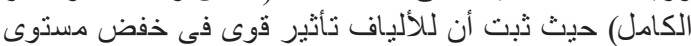
الكولسترول، والدهون في في الدم. لإن

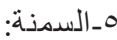

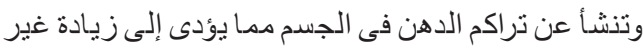

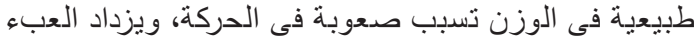

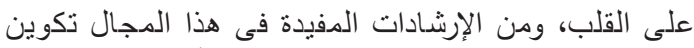

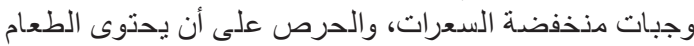

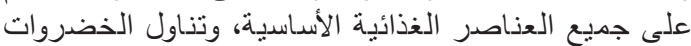
الطازجة بكثرة كالخس والجرجير والفلفل الأخضرة الأندا والإكثار من السوائل العديمة السعرات كالماء والئر والثـاي بدون سكر.

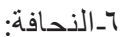

وهى ذوعان: نحافة غذائية ناتجة عن نافية ناول الفرد

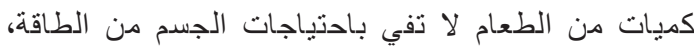

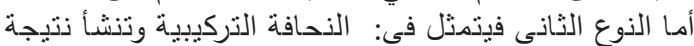

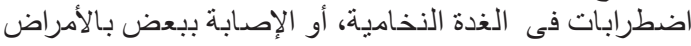

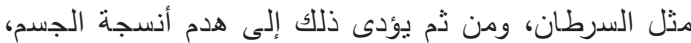


التى لا يجب تتاولها مع أطعمة أخرى :لأنها تسبب إما زيادة

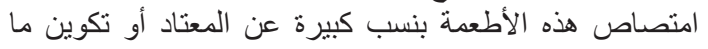

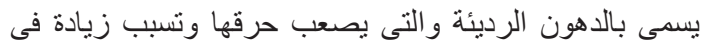

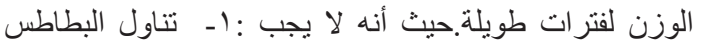

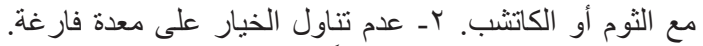

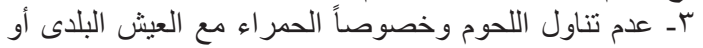

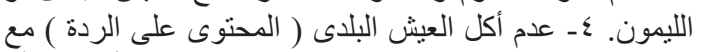

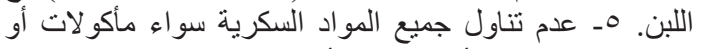

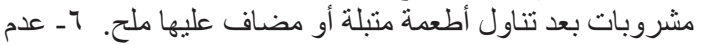

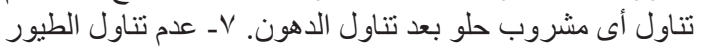

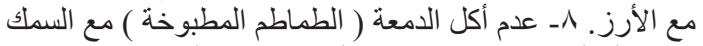

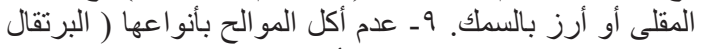

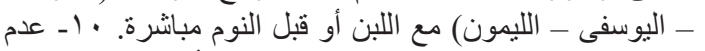

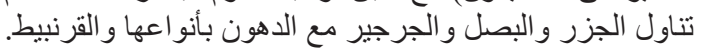

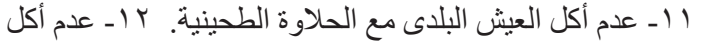

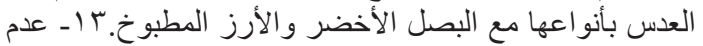

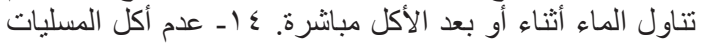

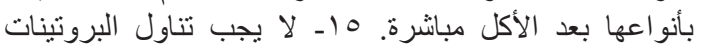

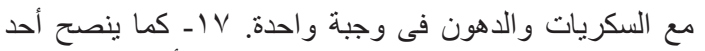

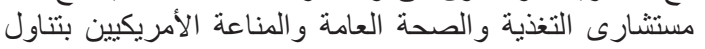

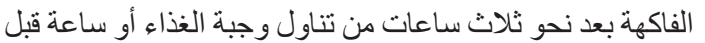
تناول العشاء ، أو تتاول وجبة كاملة من الفاكهة.

الفصل الثانى: الاور الوقائى والعلاجى للفذاء

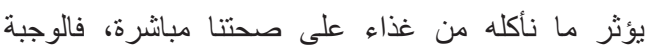

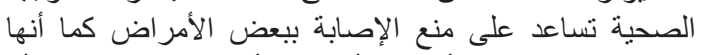

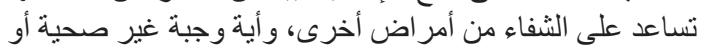

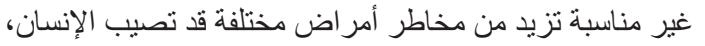

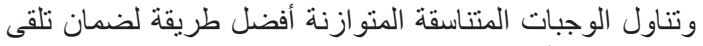

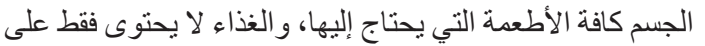

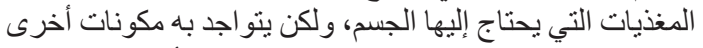

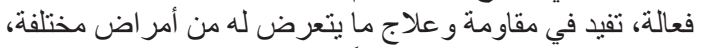

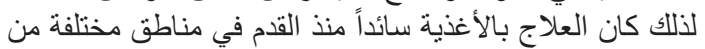

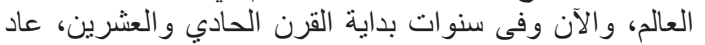

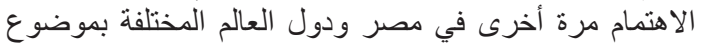

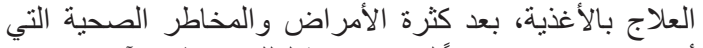

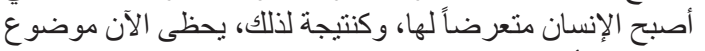

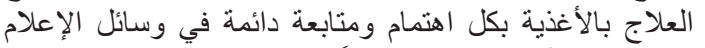

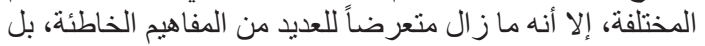

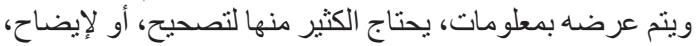

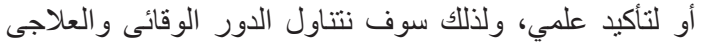
للغذاء بشيء من التفصيل: ولاكئ

أولا: الدور الوقائى والعلاجى لبعض النباتات الطبية والعطرية

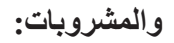

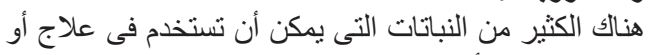

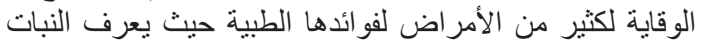

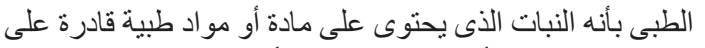

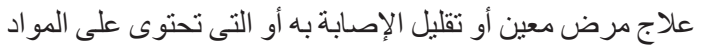

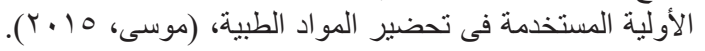

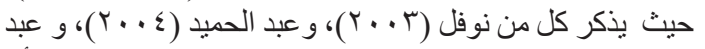

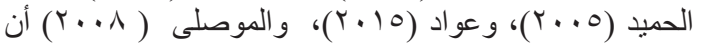

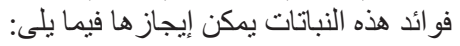

1 - نبات الكركم: من فو ائده الطبية أنه مثبط لنمو بعض الأور ام،
إذا ارتبطت بذوع من المرض، فلا تدخل ضدمن العادات

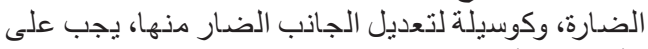

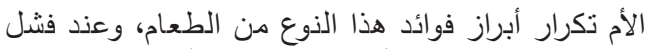
المحاولة يجب على الأم إدخال بدائل الأطعمة إلى الدى مائدة وعند

الطعام.

r-ـ عدم إنتظام دواعيد الطعام: وقد تنتسبب هذه العادة السيئة

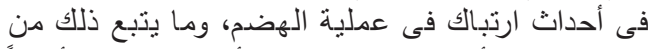

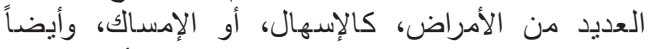

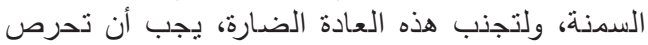

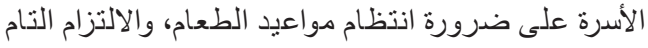

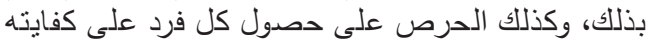

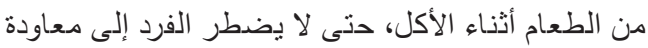

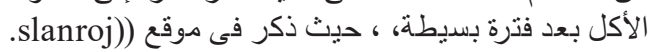
عن ب,r,egdirbmac

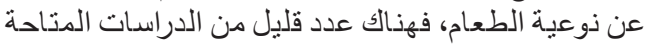

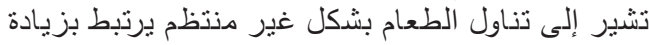

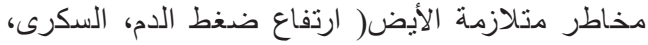

البدانة ).

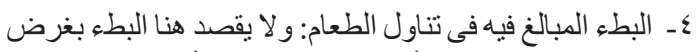

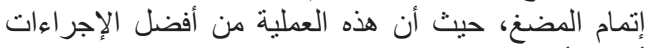

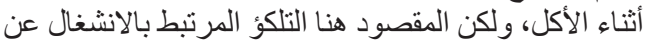

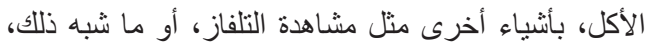

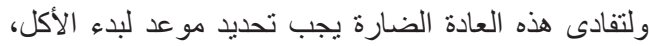

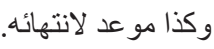

ويذكر يوسف (99 (19) بعض العادات الغذائية الخاطئة

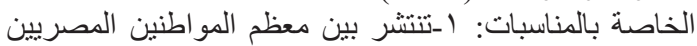
عادة الافطار صبيحة يوم عبد الثبات الفطر على الكعلك والغرينة

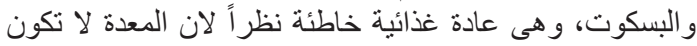

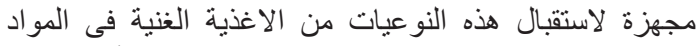

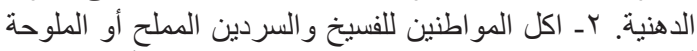

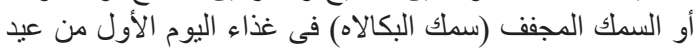

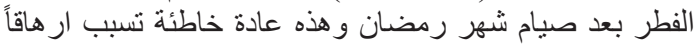

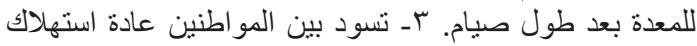

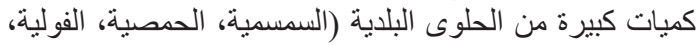

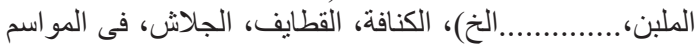

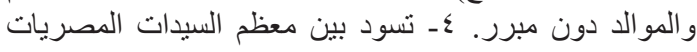

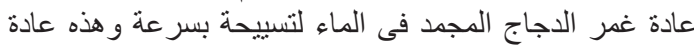
خاطئة لان ذللك يسبب فقاج الكثير من العناء العناصر الغذائية القابلة

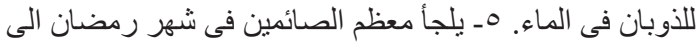

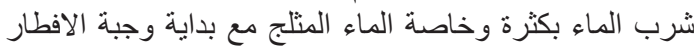

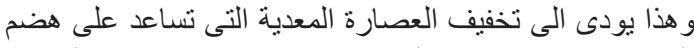

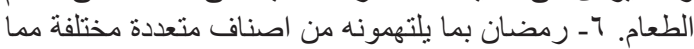

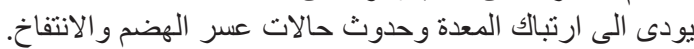

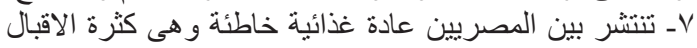

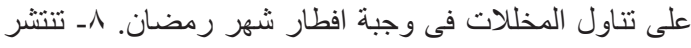

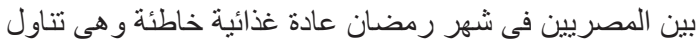

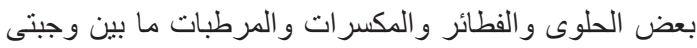

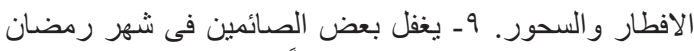

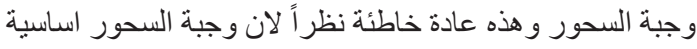

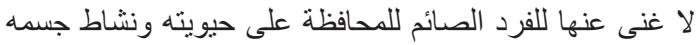

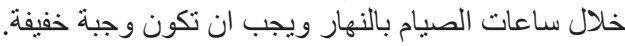

ويوضح عويضة ( 9 . . . أن هناك بعض أنواع الأطعمة

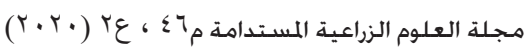




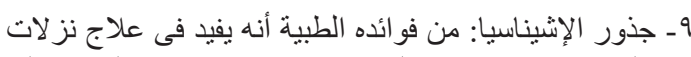

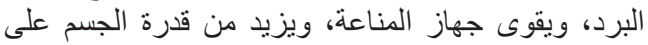

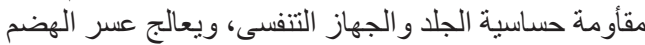

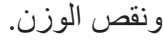

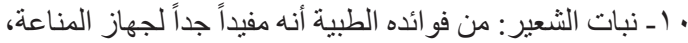

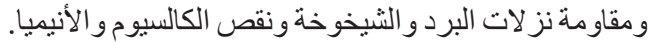

11- نبات حبة البركة: من فوائده الطبية أنه مقوى لجهاز

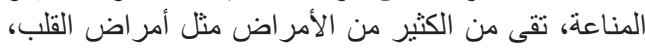

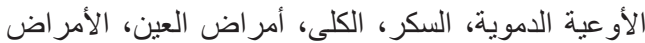

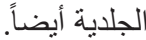

r ا ـ نبات الجنسنج: من فو ائده الطبية أنه يقوى جهاز المناعة،

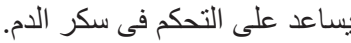

سا ـ نبات اللبان الدكر : من فو ائده الطبية أنه يستخدم لعلاج البرد و التهاب الحلق و الحنجرة، و علاج الكلى الكلى

ـ ا ـ نبات الريحان: من فو ائده الطبية أنه مهدئ ومنوم، مضاد

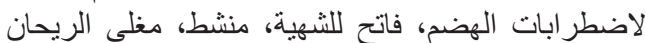

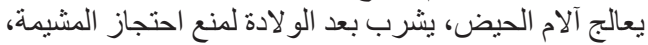
يساعد على التئام الجروح.

10 ـ نبات الحبهان: من فوائده الطبية أنه مهدئ ومنوم، ومضغ إنغ فص حبهان يقوى عضلة القلب.

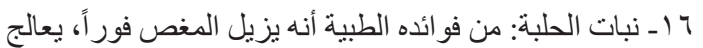

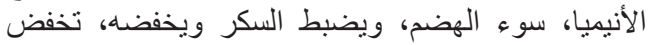

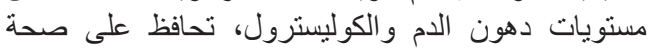
القلب.

IV - نبات السناميكى: من فو ائده الطبية أنه علاج فورى للإمساك

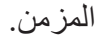

11 ـ نبات الكمون: من فوائده الطبية أنه يستخدم لإذابة دهون

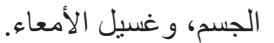

9 ا ـ نبات القرنفل: من فو ائده الطبية أنه تستخدم فى طب الأسنان لتخفيف الألم ومسكن عام، منشط ومضاد الثناد للتخمر.

• r ـ نبات الز عتر : من فو ائده الطبية أنه مطهر ، يعمل على انتظام عملية التنفس.

ا آـ نبات أكليل الجبل: من فوائده الطبية أنه يساعد على الثفاء

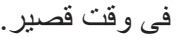

r r- نبات البابونج: من فوائده الطبية أنه مطهر، ومضاد للالتهاب، وتنظيج عملية الهضون.

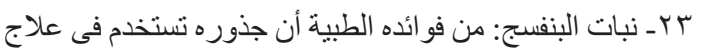

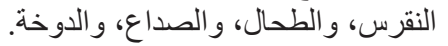
ثانياً: الاور الوقائى للفذاء:

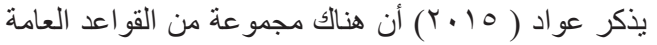
للتغذية الصحية تتمثل فيما يلى

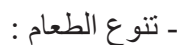
لا يمكن الاكتفاء بنوع و واحد من الطعام ـ و إلا أصيب الإنسان

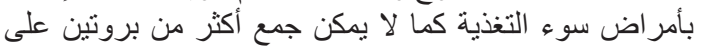

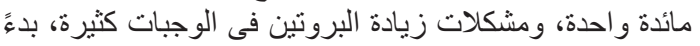

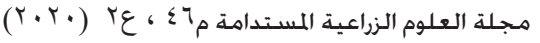

ويفيد أيضاً كمضاد للأكسدة الضارة بصحة الجسم، ومضناد

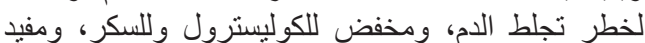
ل لتقوية المناعة.

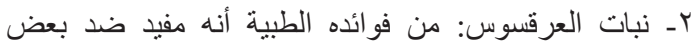

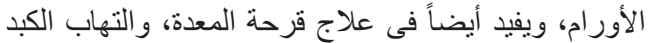

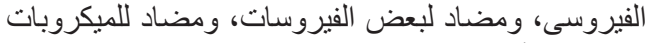

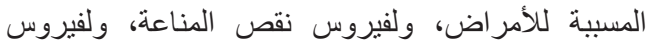

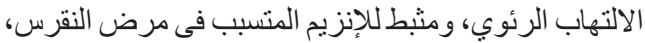
ومفيد ضد تسوس الأسنان.

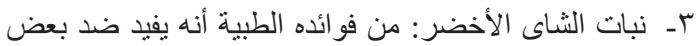

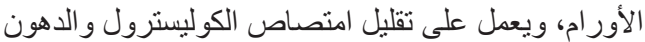

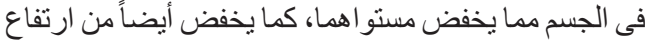

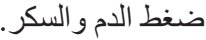

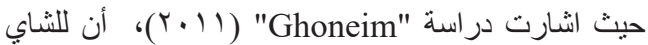
الأخضر العديد من الخصائص العلاجية : فهو يحتوى على العيد العديد العيد

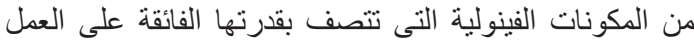

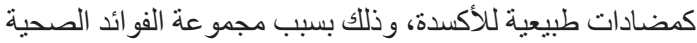

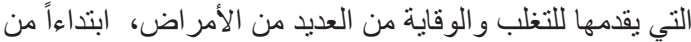

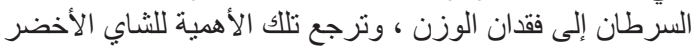
إلى احتو ائه على مركبات البولى ولى فينول ( Poly phenolic )

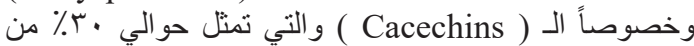
الوزن الجاف لأور اق الثاي الأخضر الجافة، و الثابي و الأخضر

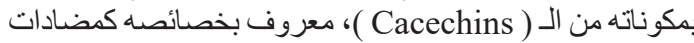

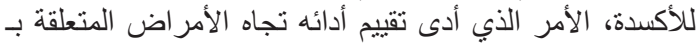
و(Reactive Oxygen Species) و أمر اض القلب وأمر اض الأعصاب.

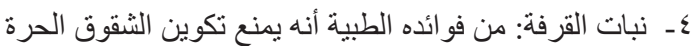

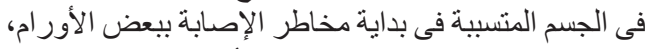

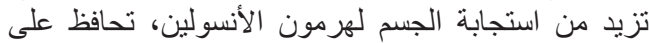

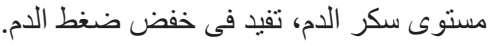

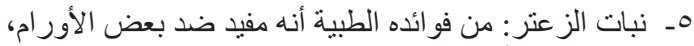

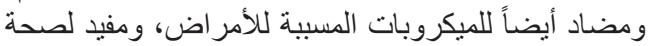

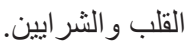

T- - نبات الينسون: من فو ائده الطبية أنه ينشط الهضم، ومزيل للانتفاخ، ومقوى للمبايض. تلنيض

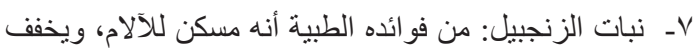

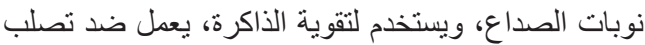

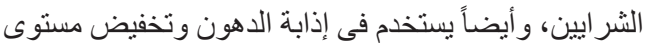

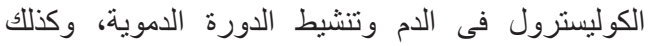

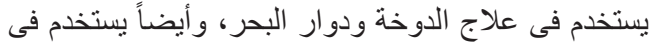

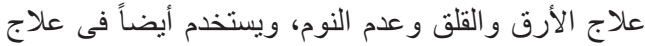

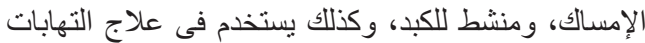
المفاصل لما يحتوى عليه من مو اد فعالة مضادة للالتهابات.

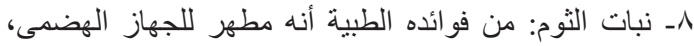

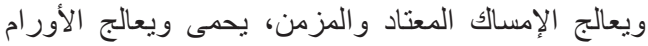

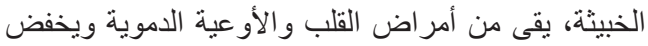

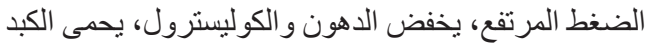

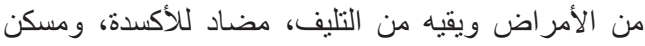
ومضاد للإلتهابات. 


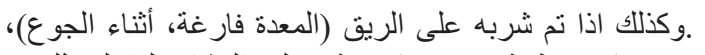

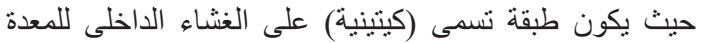

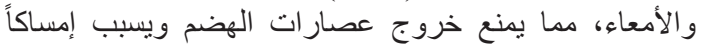

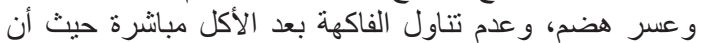

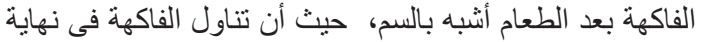

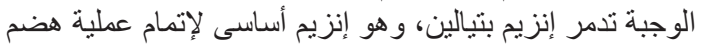

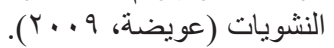

ثالثا: الدور العلاجى للغذاء (المسموح والممنوع من الإغذية

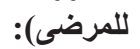

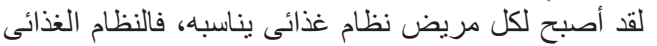

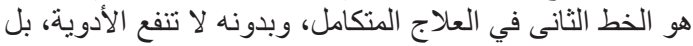

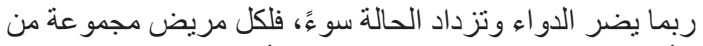

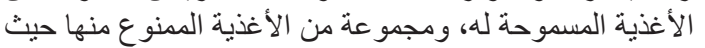

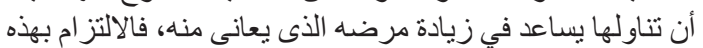

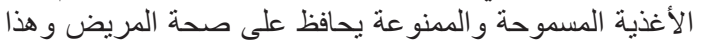
ما بطلق علية مصطلح "التغذية العلاجية"، التى تعرف الته على أنها

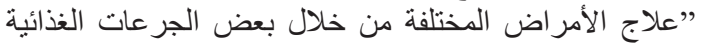

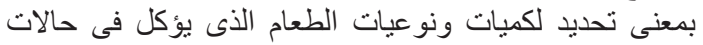

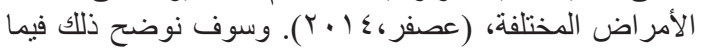

يلى:

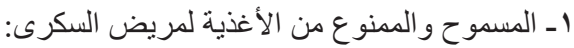

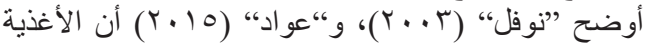

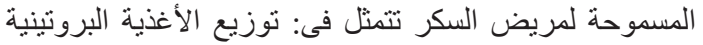

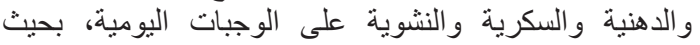

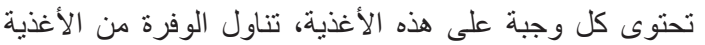

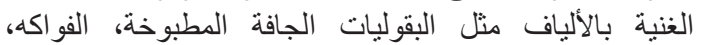

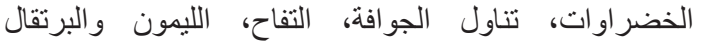

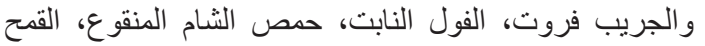

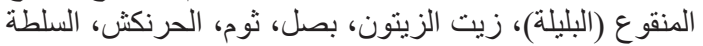

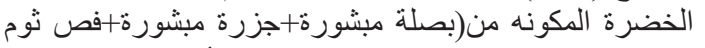

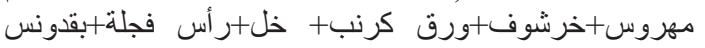

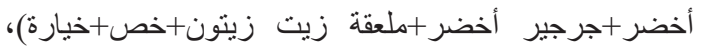

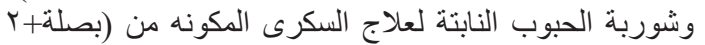

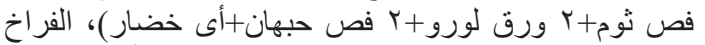

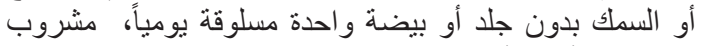

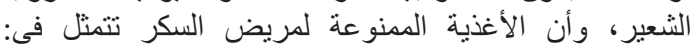

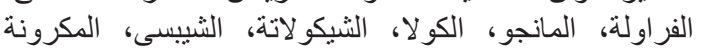

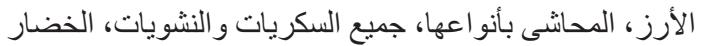

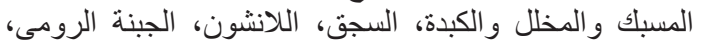
السمك المملح و الرنجة.

r ـ المسموح و الممنوع من الأغذية لمريض السمنة:

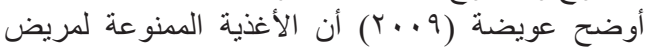

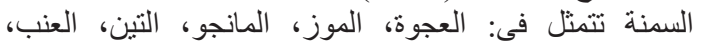

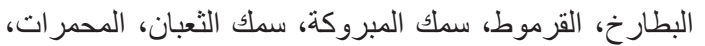

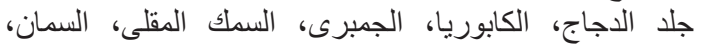

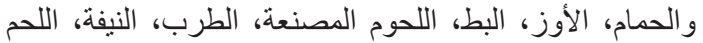

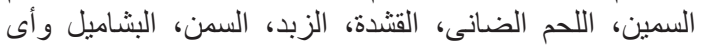

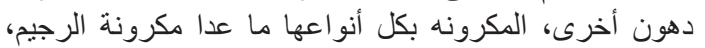

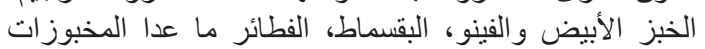

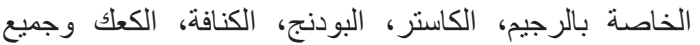

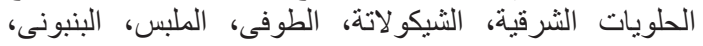

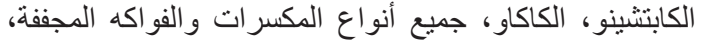

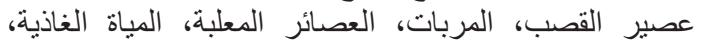

من سوء الهضم و آلام القولون ..، ونهاية بالنقرس والحصوات

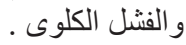

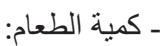

يجب أن تتناسب مع المجهود العضلى فإذا زاد المعاد المجهود

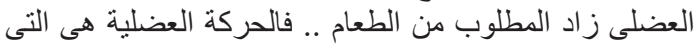
تهضم الطعام والثبات على كمية ثابته من الطعام خطأ.

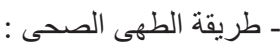

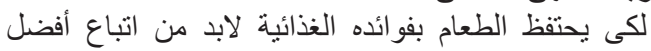

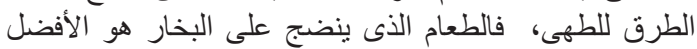

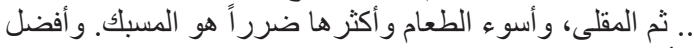

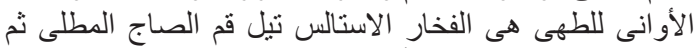

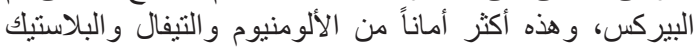

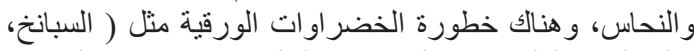

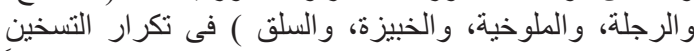

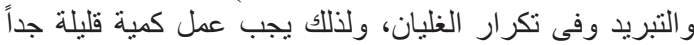

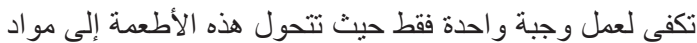

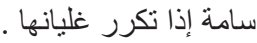
- وقت إعداد الطعام :

السلاطة الخضر اءع يتم تقطيعها قبل الأكل مباشرة، وممنوع تركها فى الثلاجة مقطعة و إلا فقدت فائدتها .

ـ عدم إستهلاك كميات كبيرة:

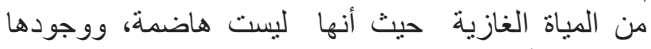

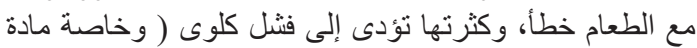

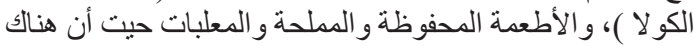

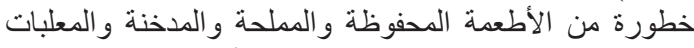

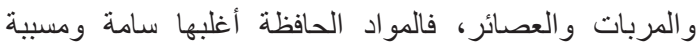

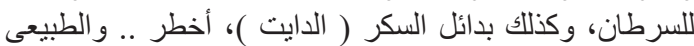

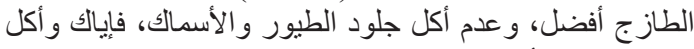

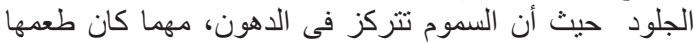

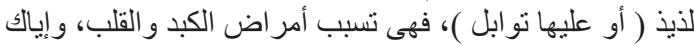

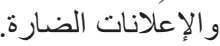

- أهمية المشروبات الصحية الدافئة:حيث أنها ضرورة وهى الإنى

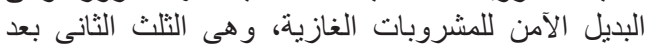

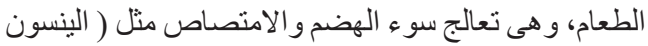

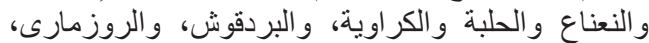

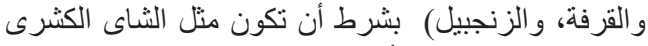

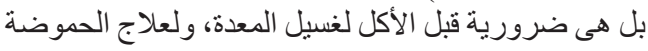
و إرتجاع المرىء.

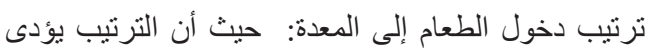

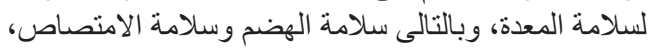

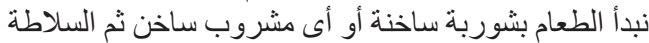

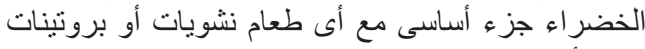

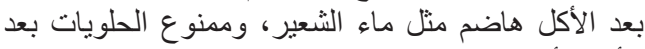

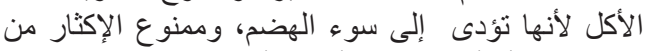
شرب الماء أو أى مشروب ألثى شؤ الأ الأكل.

و على الرغم من فو ائد الثاى و على الرغم من قلة خطورته

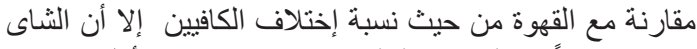
يصبح مضر اً في الحالات التالية : اذا تم شربه بعد بعد الأكل مباشرة:

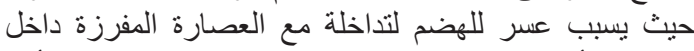
المعدة و الأمعاء، لذلك يفضل شربه بعد ساعتين من تناول الأكل

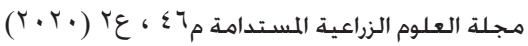


آـ المسموح و الممنو ع من الأغذية لمريض قرحة المعدة والاثني

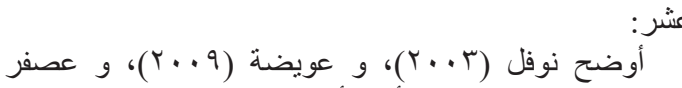

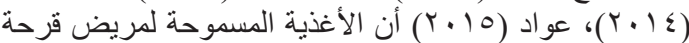

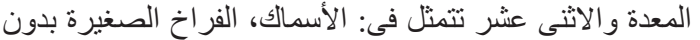

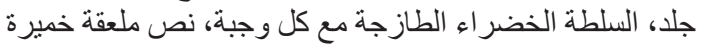

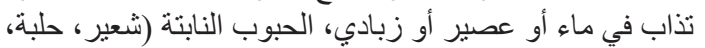

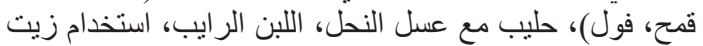

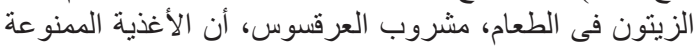

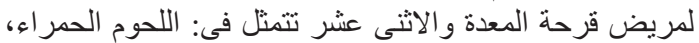

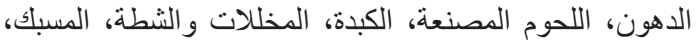

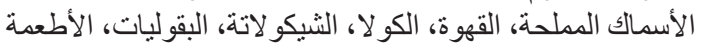

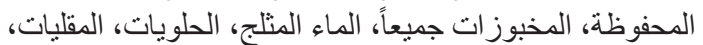

الششويات، الفو اكة الحمضية (الفراولة، الليمون، البرتقال).

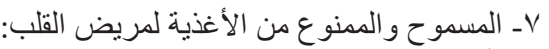

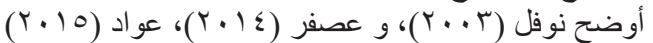

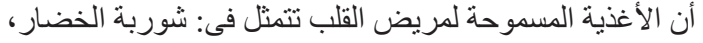

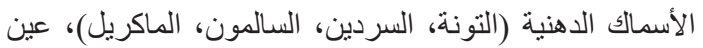

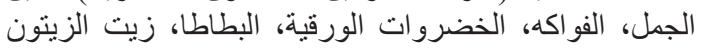

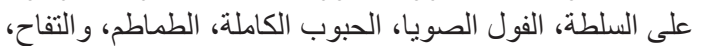

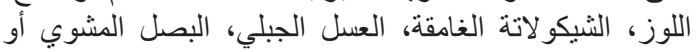

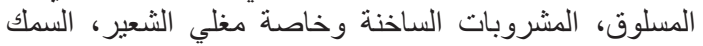

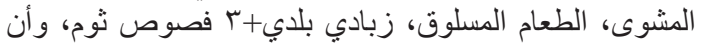

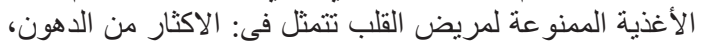

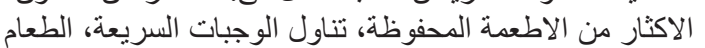

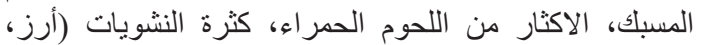
محشي ..الخ)، الطعام المملح، الطعام المشوي.

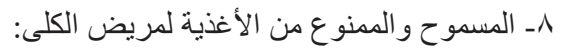

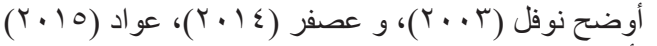

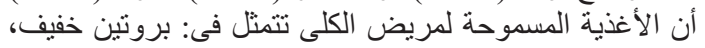

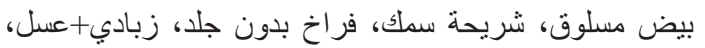

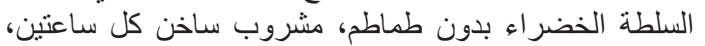

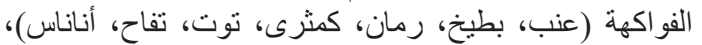

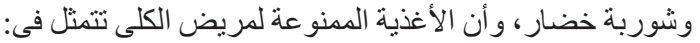

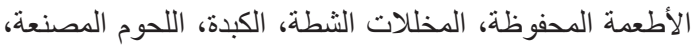

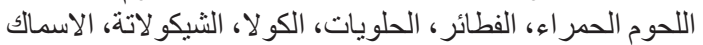

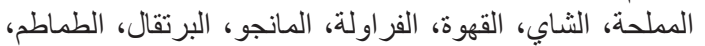

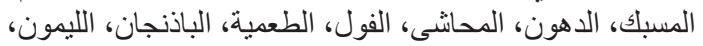
المخلل، الزيتون، المعلبات، الجبن الرومى. الرعي.

9ـ السسموح و المنوع من الأغذية لآلام المفاصل وخشونة

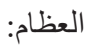

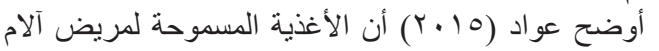

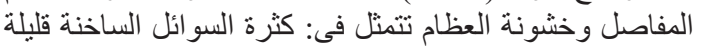

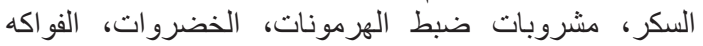

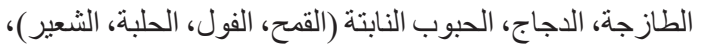

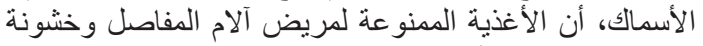

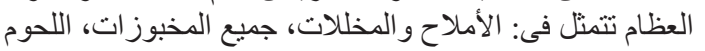

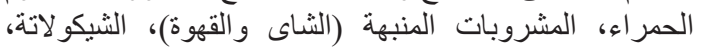

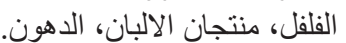

الحلويات، المسليات، البطاطس، البقول الجافة، القلقاس، البنجر ،

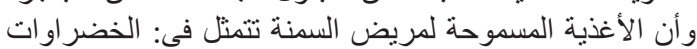

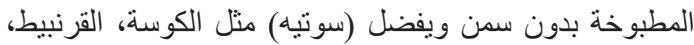

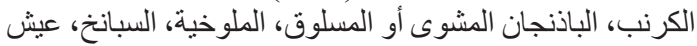

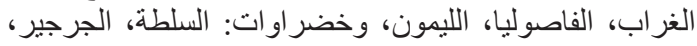

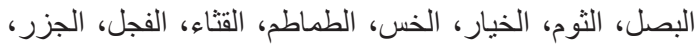

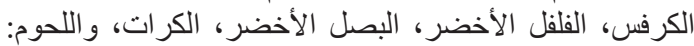

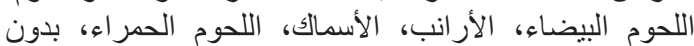
دهن، الدجاج بدون جلد، والمشروبات: الثشاى، الكركديه، القهوة الدايت، ماء تونيك.

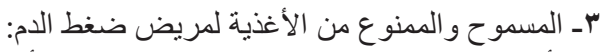

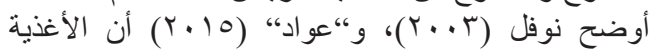

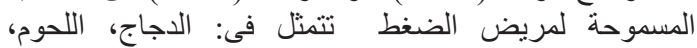

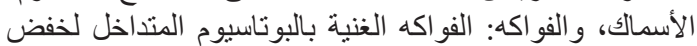

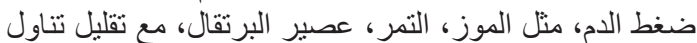

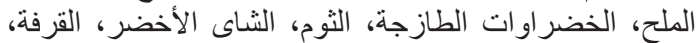

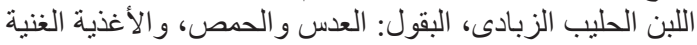

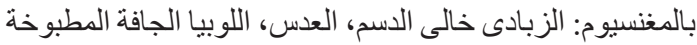

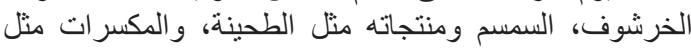

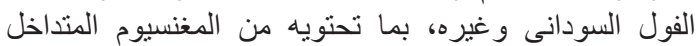

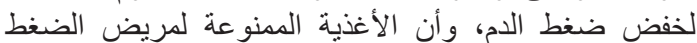

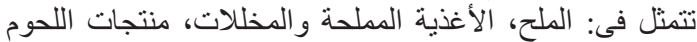

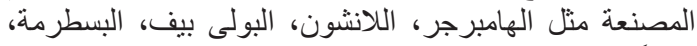
أيضاً الوجبات السريعة، الدهون، كثرة النشويات.

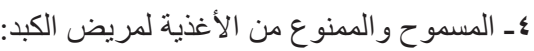

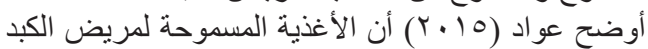

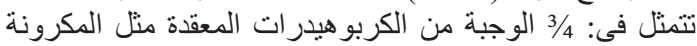

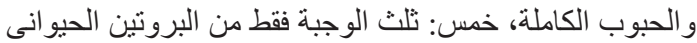

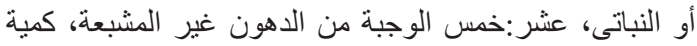

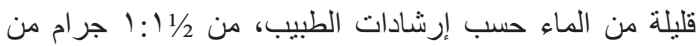

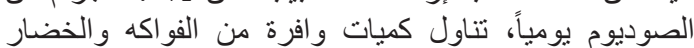

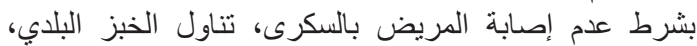

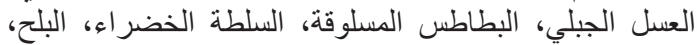

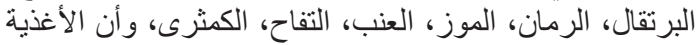

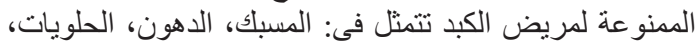

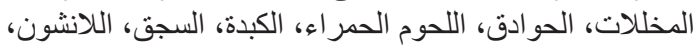

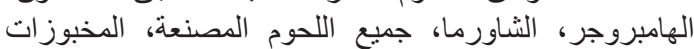

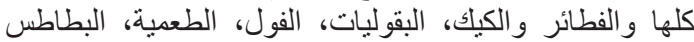

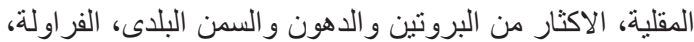
المشش، المانجو، الثنيكو لاتة، الكو لا، تعرض الزئ الزيت للنار.

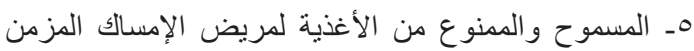

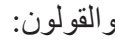

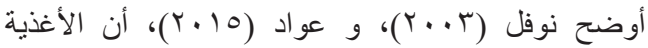

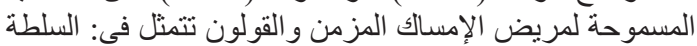

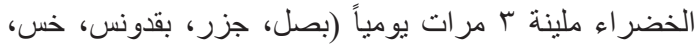

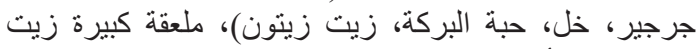

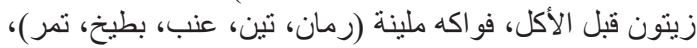

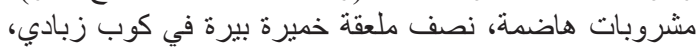

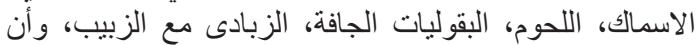

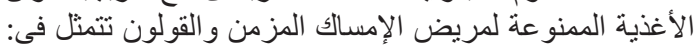

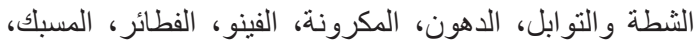
الجو افة، الباذنجان، الفلفل، الفو اكه ذات البذور . 
انخفاض المستوى المعرفي والمهارى للريفيات المبحوثات في

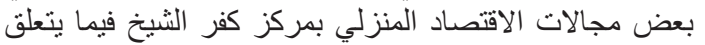

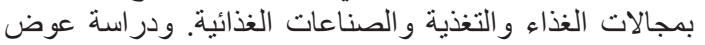

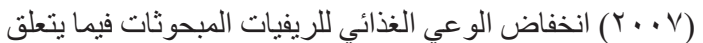

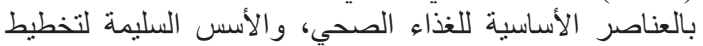

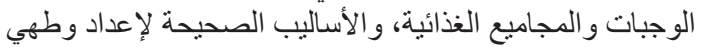

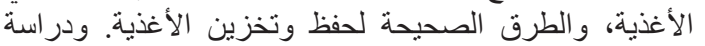

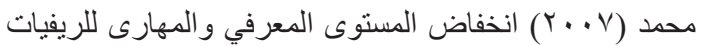

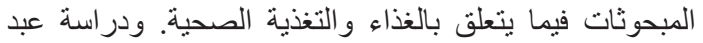

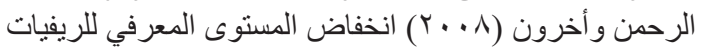

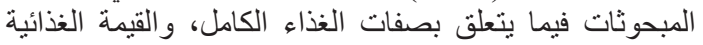

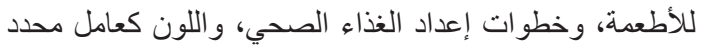

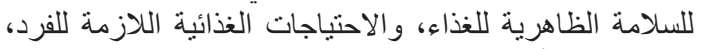

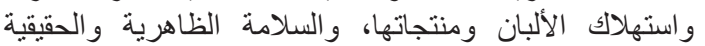

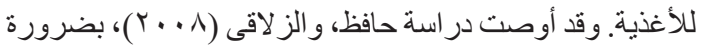

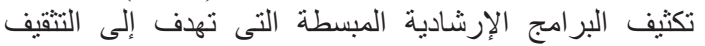

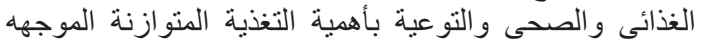

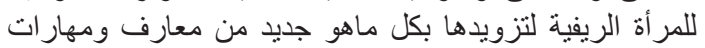

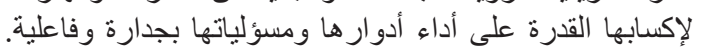

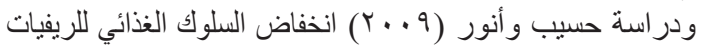

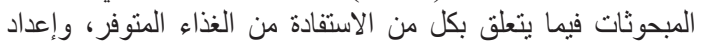

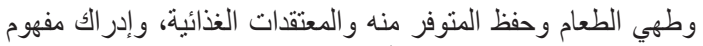

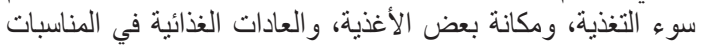

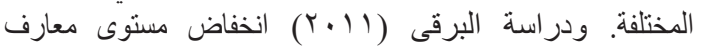

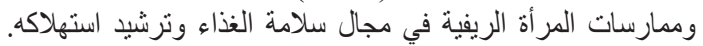

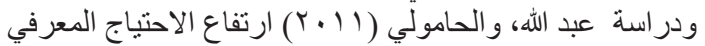

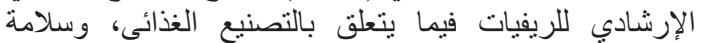

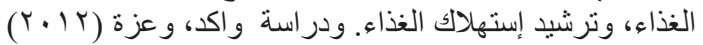

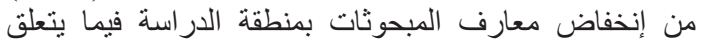

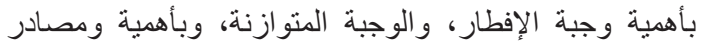

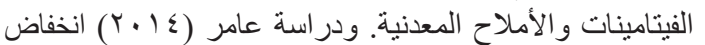
السلوك الغذائي للريفيات المبحوثات فيما بنعلق بكل من بنات بالعادات

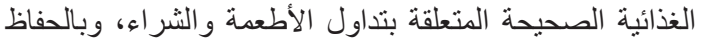

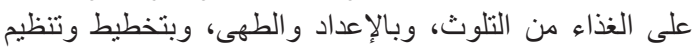

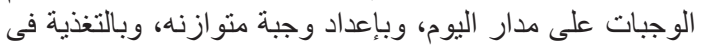

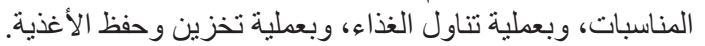

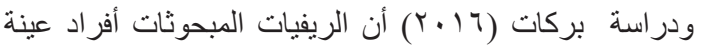

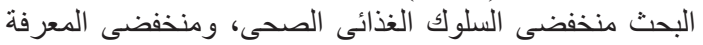

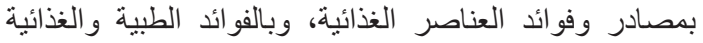

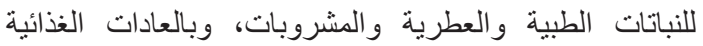

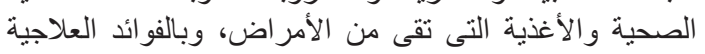

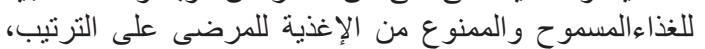

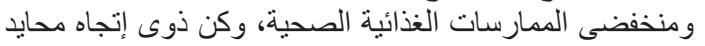

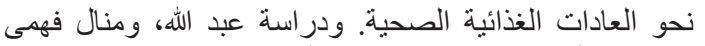

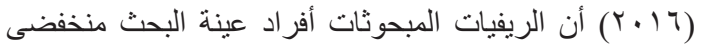

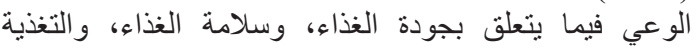

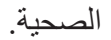

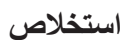
يعرض جدول (1) ملخص لبعض النقاط الرئيسية التى التى

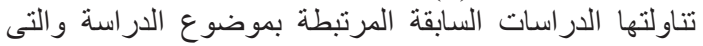

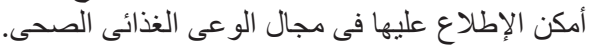

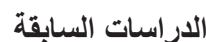

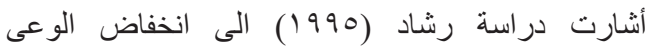

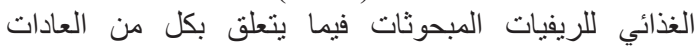

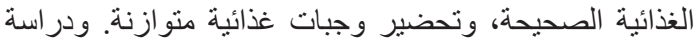

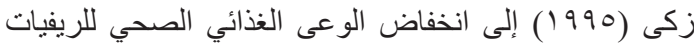

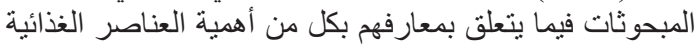

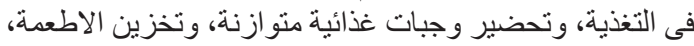

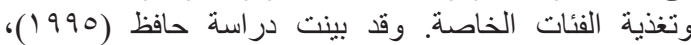

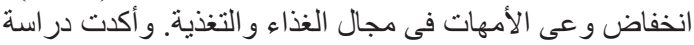

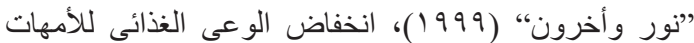

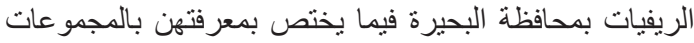

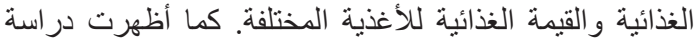

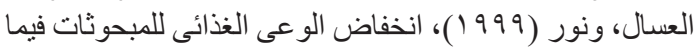

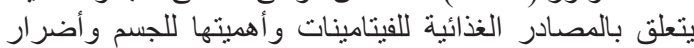

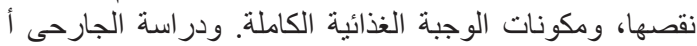

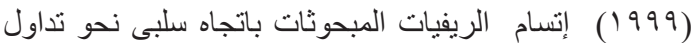

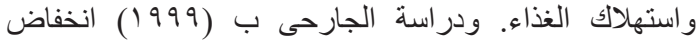

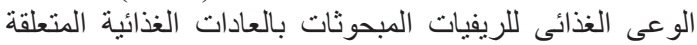

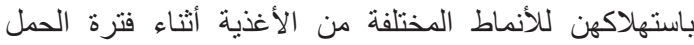

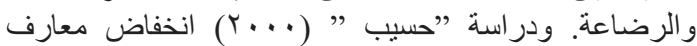
و اتجاهات وممارسات المرأة الحضرية و والريفية و البدوية فيما

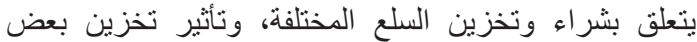

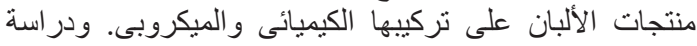

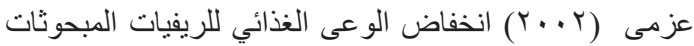

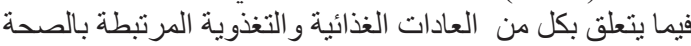

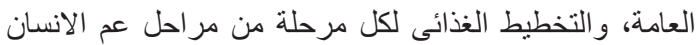

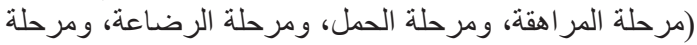

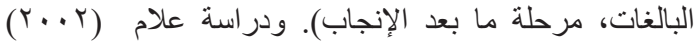

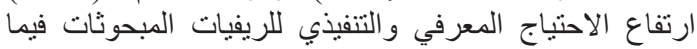

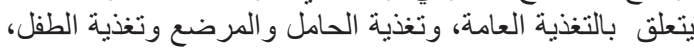

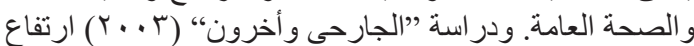

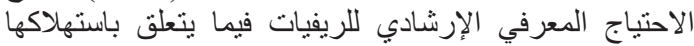

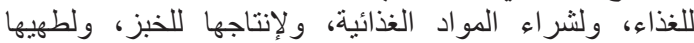

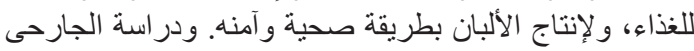

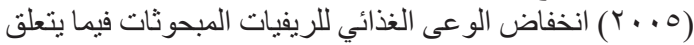

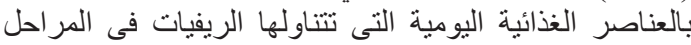

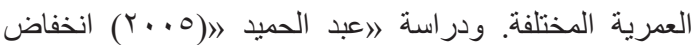

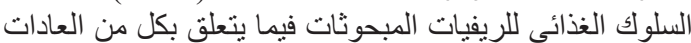

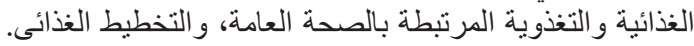

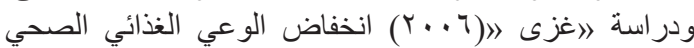

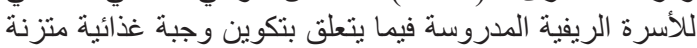

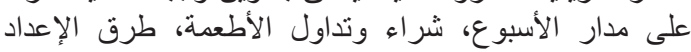

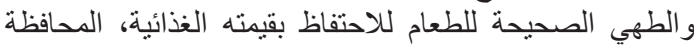

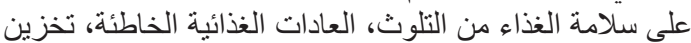

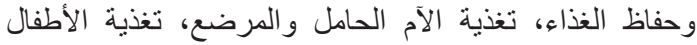

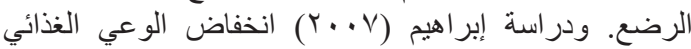

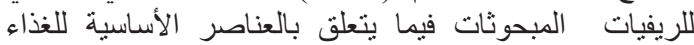

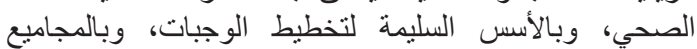

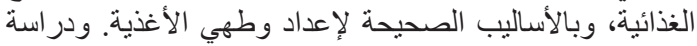

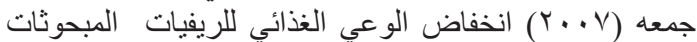

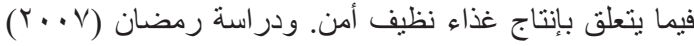


جدول اـ ملخص بأهم النقاط الرئيسية الواردة فى الدراسات والبحوث السابقة

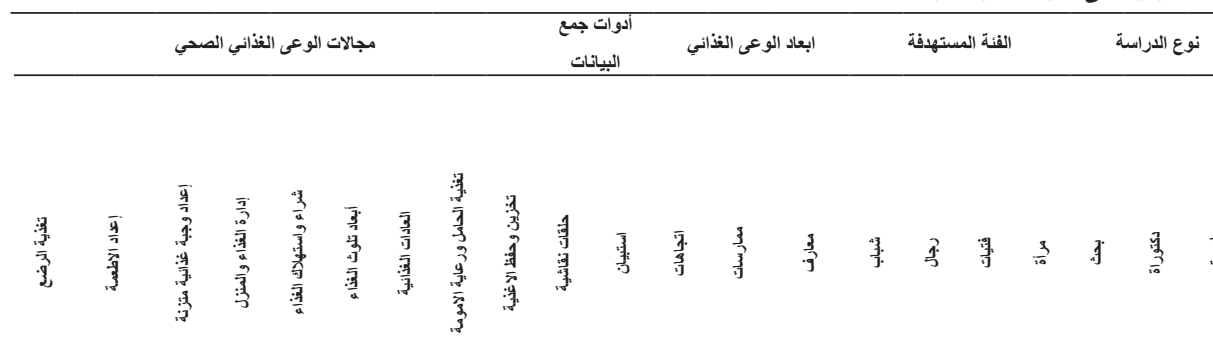

$$
\begin{aligned}
& \text { رشاد } 1990 \\
& \text { 1990 }
\end{aligned}
$$

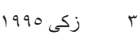

$$
\begin{aligned}
& \text { ؛ } \\
& \text { الجارحى(ب) } \\
& \text { ] } \\
& \text { العسال ونور } 1999 \\
& \text { حسيب r... }
\end{aligned}
$$

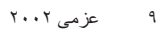

$$
\begin{aligned}
& \text { 1... }
\end{aligned}
$$

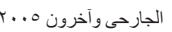

$$
\begin{aligned}
& \text { r...0 الحميد } \\
& \text { r } \\
& \text { S ابراهيي ب... }
\end{aligned}
$$

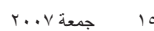

$$
\begin{aligned}
& \text { Y...Y }
\end{aligned}
$$

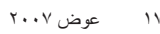

$$
\begin{aligned}
& \text { Y... محمد }
\end{aligned}
$$

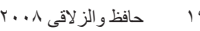

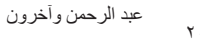

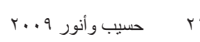

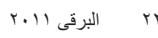

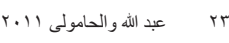

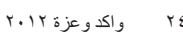

$$
\begin{aligned}
& \text { r. ع عامز ro }
\end{aligned}
$$

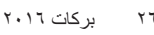

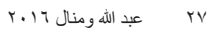

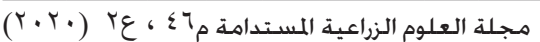




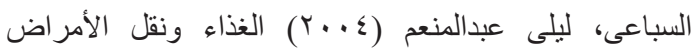

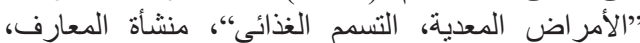
بالإسكندرية.

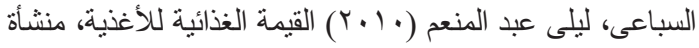
المعارف جلال حزى وشركاه، محطة الرمل - الاسكندرية.

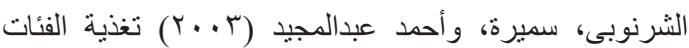
الحساسة، مكتبة بستان المعرفة، كفر الدوار البر

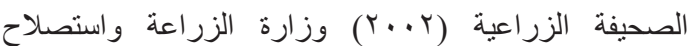
الأراضي، مجلد Vه، العدد الخامس.

العسال، أمال السيد، ونور، سهير( 999 (199 ) ، العلاقة بين تناول

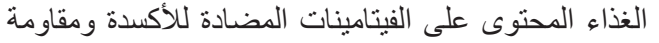

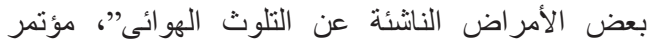

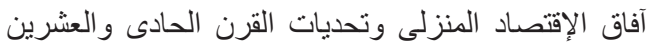

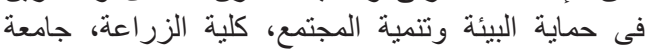
الإسكندرية.

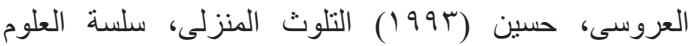
و التكنولوجيا للجميع، مكتبة المعارف الجديدة، الاسكندرية.

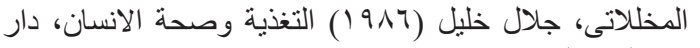

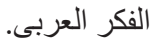

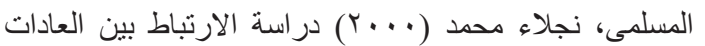

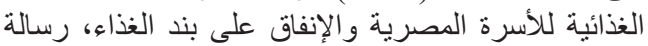
ماجستير، كلية الاقتصاد المنزلي، جامعة المنوفية لإنية

المعهد الكاريبى للتغذية والطعام (•99 (199 ) دليل التخذية للعاملين

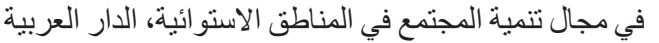

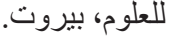

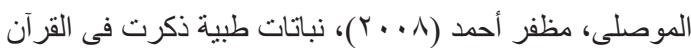

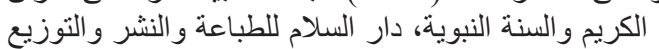
و الترجمة، مدينة نصر ، القاهرة، دارة

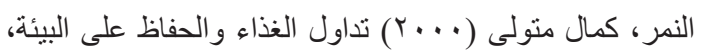

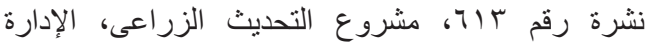

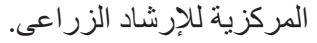

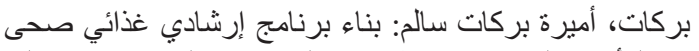

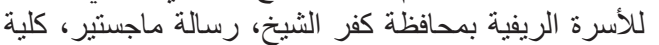

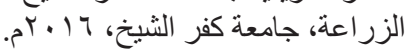

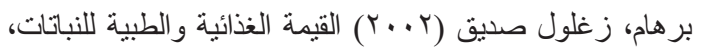
مؤسسة أم القرى للترجمة و النشر و التوزيع مصر - المنصورة.

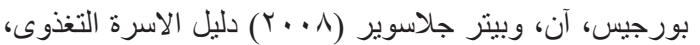
منظمة الاغذية والزر اعة، الامد المع المتحدة، روما.

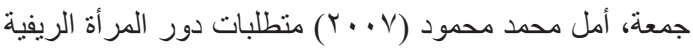

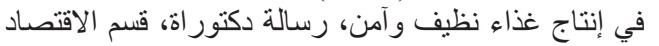

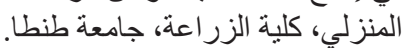

حافظ، نيفين مصطفى محمد (1990) تخطيط وتنفيذ وتقييم

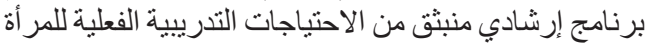

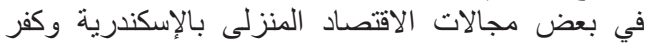
الدو ار، رسالة دكتور اة غير منشورة، قسم الاقتصاد الإنس المنزلى، وكنى
المراجع

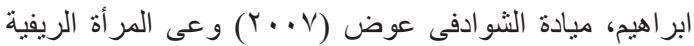

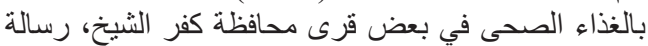

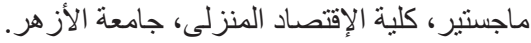

أبو طور ، السيد محمد، (0 . . ب) التغذية وتخطيط الوجبات وقو ائم

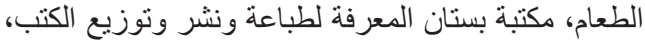
جامعة الإسكندرية.

أحمد، سمير محمد، وحسن عبد الرؤوف الهندى (r . . r) تغذية الانسان، مكتبة بستان المعرفة للنشر و التوزيع.

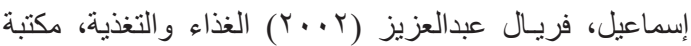
الفلاح، القاهرة. ترال.

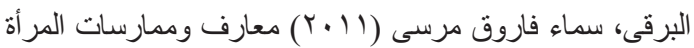

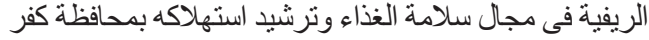
الثيخ، رسالة دكتور اة، كلية الزر اعة، جامعة كفر الثيخ.

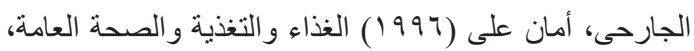

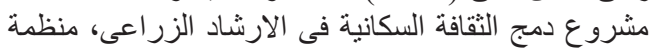

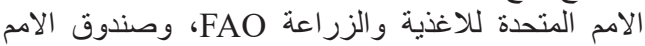
المتحدة للسكان، وزارة الزر اعة واستصدلاح الأر اضي.

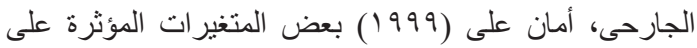

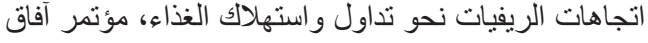

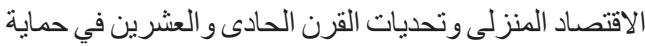

البيئة وتنمية المجتمع، كلية الزر اعة، جامعة الإسكندرية.

الجارحى، أمان على، وخديجة مصطفى محمد، و عفاف ميخائيل

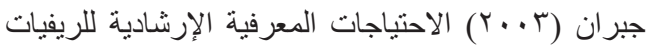

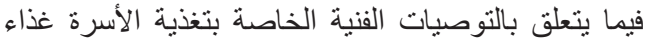

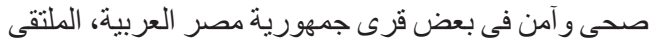

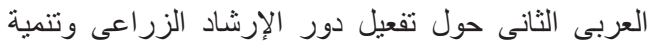

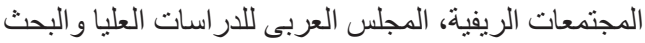

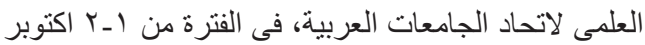

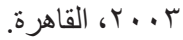

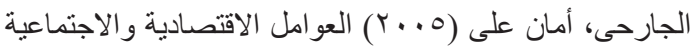

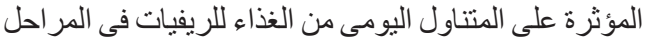

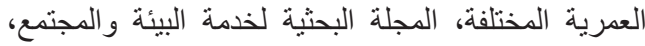

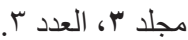

الجارحى، أمان على، وخديجة مصطفى محمد، و عفاف ميخائيل

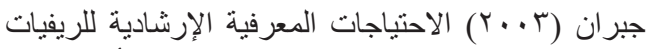

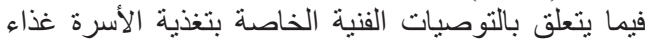

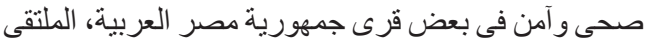

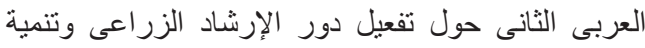

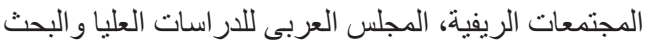

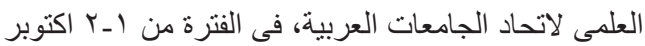

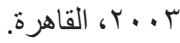

الحديدى، جمال سعد (7 ( • ب ) أمر اض سوء التغذية، نشرة عيون

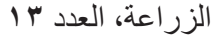

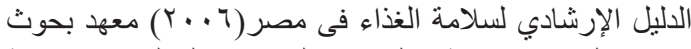

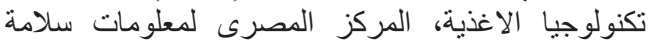

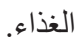




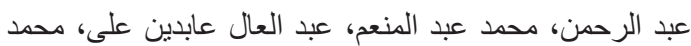

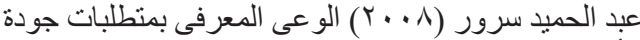

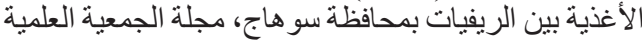
للإرشاد الزر اعي، مجلد بات اله العدد بآ.

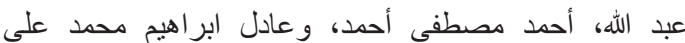

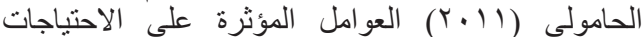

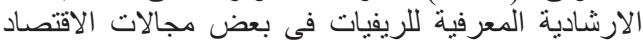

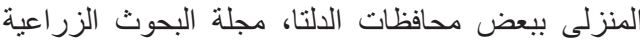

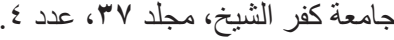

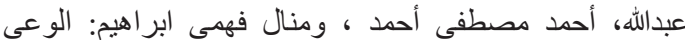

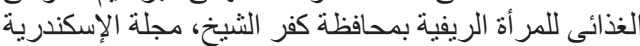

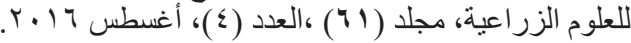

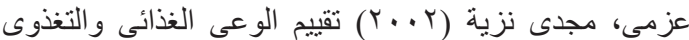

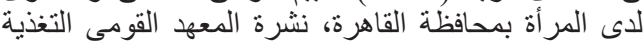

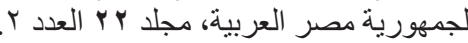

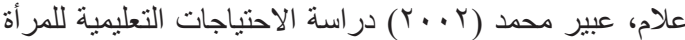

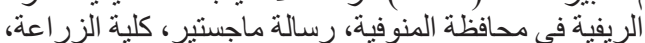

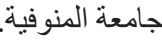

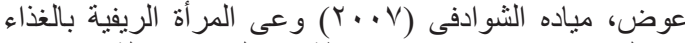

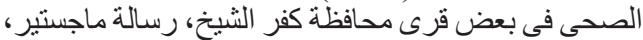

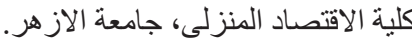

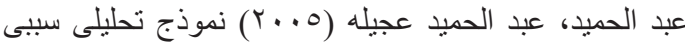

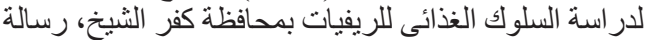
ماجستير، كلية الزر اعة بكفر الثيخ، جامعة طنطا. لأنطا.

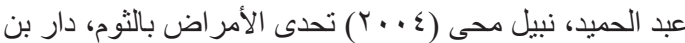
لقمان للنشر و التوزيع، كلية الصيدلة جامعة كفر الثيخ.

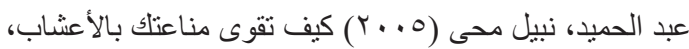
مكتبة جزيرة الورد بالمنصورة، كلية الصيدلة جامعة كفر بلاعلئ الثيخ.

عبدالرحمن، طارق محمد ( •99 (19) التغذية الصحية من الطفولة

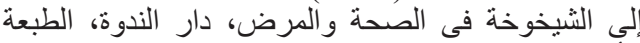

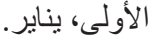

عبد القادر، منى خليل، وهالة أحمد السيد عونى، و ايمان محمد الطيل

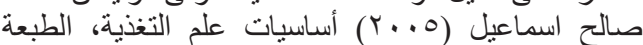
الاولى، مجمو عة النيل العربية، مدينة نصر، القيات القاهرة.

عبد المجيد، فادية يوسف (0 . × ب) تغذية الطفل، الدار المصرية السعودية للطباعة و النشر ، القاهرة.

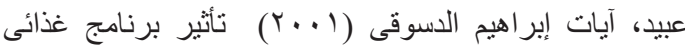

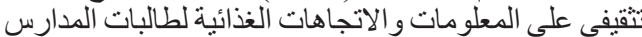
الثانوية بمحافظة المنوفية، رسالة ماجستير، كلية الاقتصات الثادية

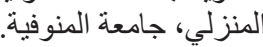

عصفر، مصطفى محمد حسين (ع أب) التغذية والغذاء في الصحة و العلاج، جامعة أم القرى.

علوي، علوية ( • 99 ( ) أهمية التغذية السليمة للأسرة مع التركيز

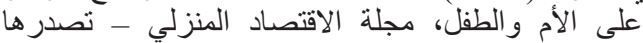
الجمعية المصرية للاقتصاد المنزلي بكلية الاقتصاد المنزلي، لإلي،

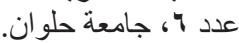

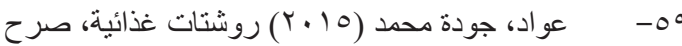

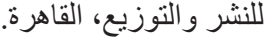

كلبة الزر اعة، جامعة الإسكندرية.

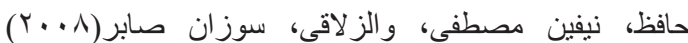

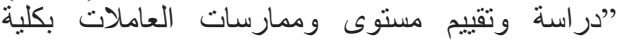

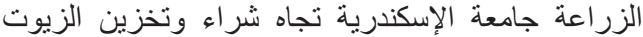

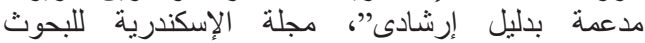

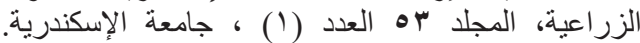

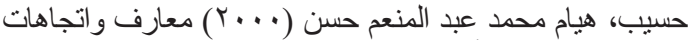

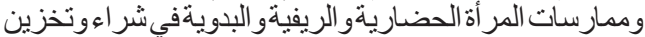

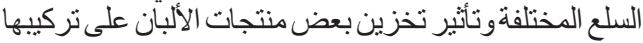

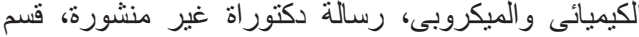
الاقتصاد المنزلى، كلية الزر اعة، جامعة الإسكندرية.

حسيب، هيام محمد عبد المنعم حسن، ومروى محسن أنور (9 . . ب ج)

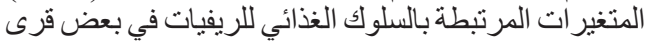

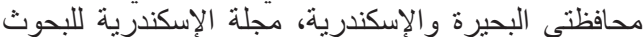

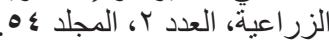

خانففنى، ورفيدة حسنين، وخالد على البرقى ( 99 (9) التغذية خلال مر احل العمر، دار المدن بجدة.

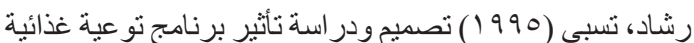

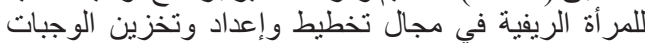
والاطعمة، نشرة بحوث الاقتصاد المنزلى، العدد الخامس،

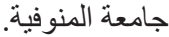

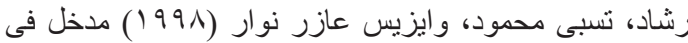

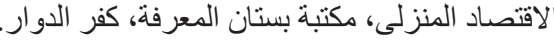

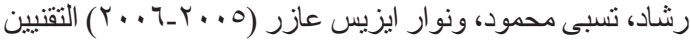

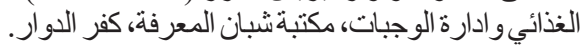

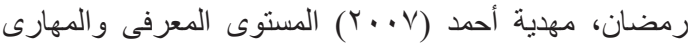

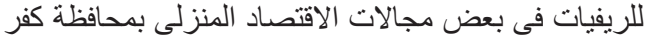

الثيخ، رسالة دكتور اه، كلية الزر اعة، جالئهاد المعة كفر الثيخ.

زكى، نادية نبيل (990 1) الاحتياجات الإرشادية للمر أة الريفية

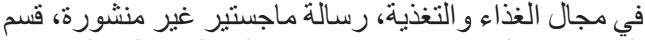

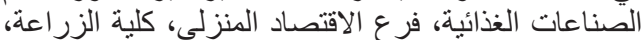

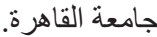
سابا، نرجس حبيب (Y. . . . الطهى علم وفن، دار المعارف

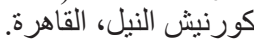

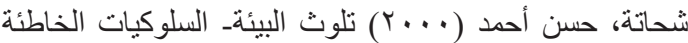

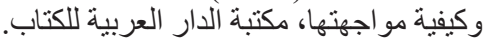

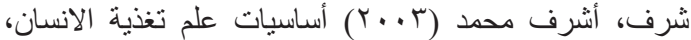

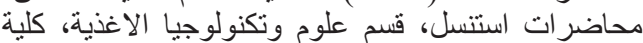

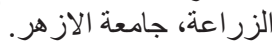

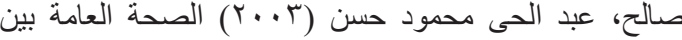

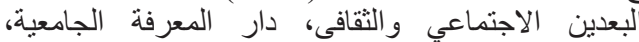
الثاطبى، الإسكندرئة.

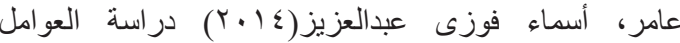
الاجتماعية والبيئية المرتبطة بسلوك كالرئية الريفيات نحو العادات

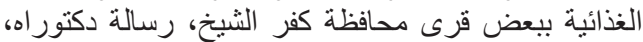
كلية الزر اعة، جامعة المنصورة.

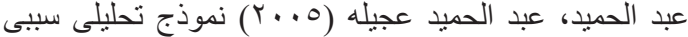

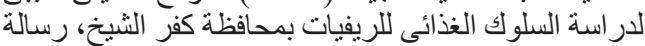
ماجستير ، كلية الزر اعة بكفر الثيخ، جامعة طنطا.

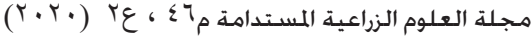




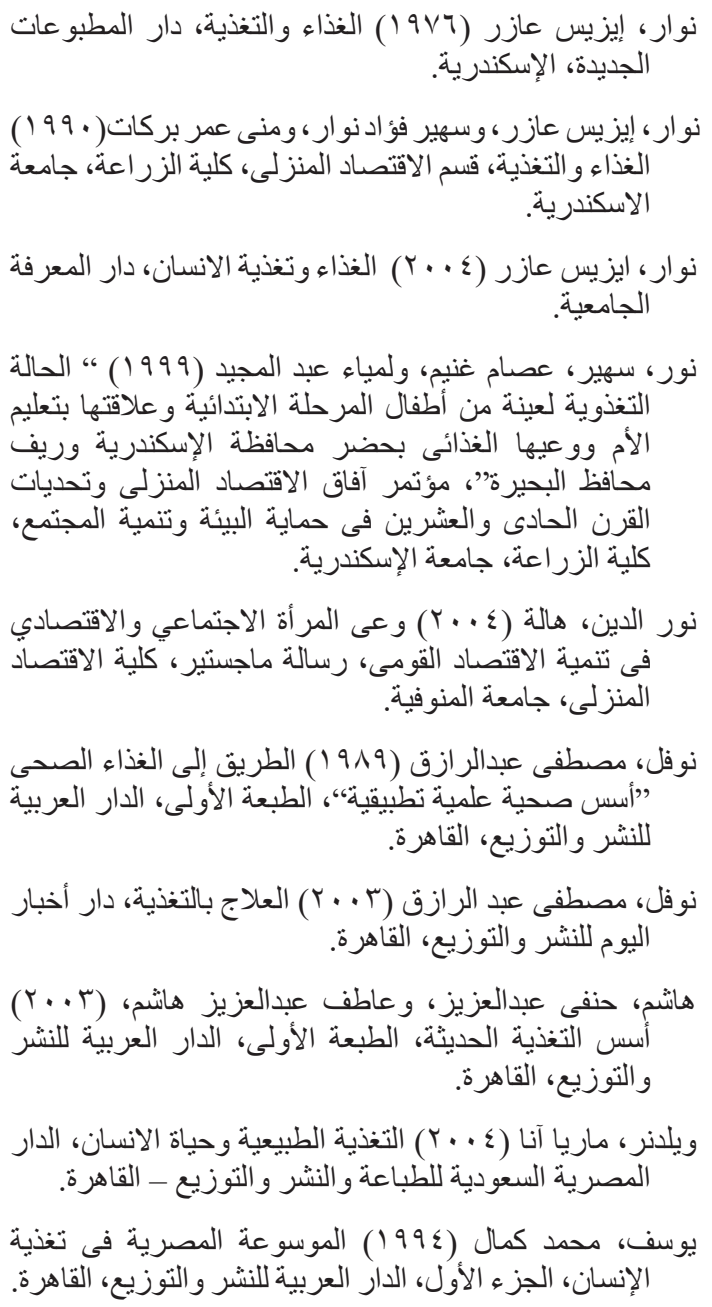

ثانياً: المراجع باللغة الانجليزية

1- Ghoneim, Heba Ahmed Ebraheim (2011), The Effect Of Some Technological Treatments On The Phytochemical Properties Of Green Tea, Master in Home Economics (Nutrition and Food Science), Faculty of Home Economics, Minufiya university.

2- Gandy-Joan Webster \& et al (2014), Oxford Hand Book of Nutrition And Dietetics, by oxford university press, Inc., New York.

3- L.kathleen, Mahan\& Janice L.Raymond.(2017): 'Krouse's Food \& The Nutrition care process', 14 ${ }^{\text {th }}$ Edition, Book Aid International. Canada.

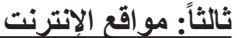

1- Site:http://jornals.cambridge.org/action/login, 2016.

$$
\begin{aligned}
& \text { عويضة، عصام بن حسن (999 199 ) تخطيط الوجبات الغذائية، دار } \\
& \text { النشر العلمى و المطابع، جامعة الملك سعود. }
\end{aligned}
$$

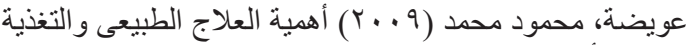

محروس، فوزى نعيم، وأحمد جمال الدين وهبه (1997 (1) الغذاء

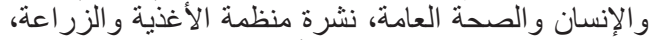
وزارة الزراعة واستصلاح الأراضي، الإدارة المارة المركزية الإنية

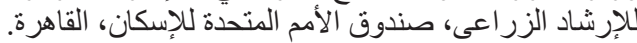

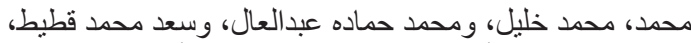

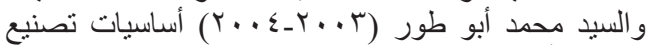

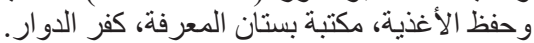

محمد، هبه عبد الفتاح شحتة (Y.V.V) مستوى معلومات وممارسات المر أة الريفية في مجال التغذية بقرية داتية دار السلام

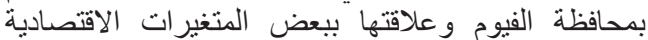
و الاجتماعية، رسالة ماجستير ، كلية الزر اعة، جامعة القاهرة.

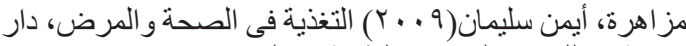
اثر اء للنشر و التوزيع، الطبعة الاولى، عمان.

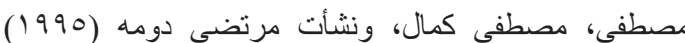
الأطعمة والتغذية فى المنازل و والفنادق و المطاعم، المئه المكتبة

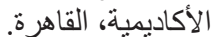

منظمة الأغذية والزر اعة للأمم المتحدة( ـ 99 1) الغذاء و التغذية

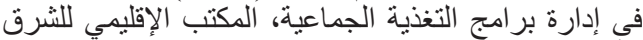

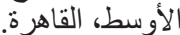

موسى، جهاد محمد (10 ب ب) النباتات الطبية و العطرية، العدد

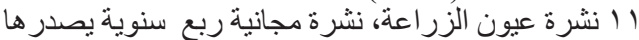
مجموعة باحثين من مركز البحوث الزئة الزراعية والجة الجامعات المصرية نشرة عيون الزرن من ماعة.

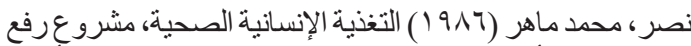

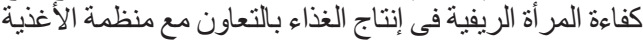

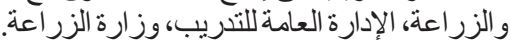




\title{
Guiding Recommendations for Feeding the Family a Healthy and Safe Food: The Preventive and Curative Role of Food
}

\author{
Ahmed M. Abdullah ${ }^{1 *}$, Noha E. Hassan ${ }^{2}$ and Amira B Barakat ${ }^{1}$ \\ ${ }^{1}$ Agricultural Extension Branch - Department of Agricultural Economics - Faculty of \\ Agriculture - Kafr El-Sheikh University \\ ${ }^{2}$ Agricultural Extension and Rural Development Research Institute - ARC.
}

$\mathbf{F}$ OOD is the first requirement of the human being, which cannot be dispensed with. Through it, he can obtain energy and the ability to resist diseases and thus be able to work and produce, which will positively affect the development of society as a whole, and proper nutrition is considered the main pillar of the health of the individual, and given the close link between the life of the individual and the quality Its food, and the nature of its nutrition, so it is extremely important that individuals in general, and those in charge of preparing food in particular, have sufficient information about food in terms of its concept, components, sources, functions, and safety, as well as with regard to nutrition in terms of its concept, as well as malnutrition And diseases of malnutrition, whereby following the principles of proper nutrition becomes an individual less susceptible to disease and enjoys good health and becomes able to work and enjoy his life, and proper nutrition affects the level of individual health and reduces diseases of malnutrition which leads to increased production and provision of what is spent on treatment and medication As a result of malnutrition, a healthy diet helps prevent some diseases and helps to cure other diseases. 